\title{
Titus Phase Ancestral Caddo Vessels from Sites in the Big Cypress Creek and White Oak Bayou Basins in East Texas
}

Timothy K. Perttula

Follow this and additional works at: https://scholarworks.sfasu.edu/ita

Part of the American Material Culture Commons, Archaeological Anthropology Commons, Environmental Studies Commons, Other American Studies Commons, Other Arts and Humanities Commons, Other History of Art, Architecture, and Archaeology Commons, and the United States History Commons

Tell us how this article helped you.

This Article is brought to you for free and open access by the Center for Regional Heritage Research at SFA ScholarWorks. It has been accepted for inclusion in Index of Texas Archaeology: Open Access Gray Literature from the Lone Star State by an authorized editor of SFA ScholarWorks. For more information, please contact cdsscholarworks@sfasu.edu. 


\section{Titus Phase Ancestral Caddo Vessels from Sites in the Big Cypress Creek and}

White Oak Bayou Basins in East Texas

\section{Creative Commons License}

(c) (1) (9)

This work is licensed under a Creative Commons Attribution-NonCommercial 4.0 International License 


\title{
Titus Phase Ancestral Caddo Vessels from Sites in the Big Cypress Creek and White Oak Bayou Basins in East Texas
}

\author{
Timothy K. Perttula
}

\section{Introduction}

This article is a summary of the findings from the documentation of 889 ancestral Caddo ceramic vessels from 20 sites in the Sulphur River and Big Cypress Creek basins in Camp, Franklin, Harrison, Marion, Morris, Titus, and Upshur counties in East Texas (Figures 1 and 2; Table 1). Four vessels are from an Early Caddo period burial at the J. E. Galt site (41FK2), but the remainder are from Late Caddo period Titus phase (ca. A.D. 1430-1680) burial features. In the comparisons of Titus phase vessel assemblages that follow, the focus will be strictly on the larger Titus phase vessel assemblages in the documentation study (see Perttula 2018), namely those from sites with more than 23 vessels, thus including the vessels from the P. S. Cash (41CP2), Jonah C. Atkinson Farm (41FK1), J. E. Galt, Mattie Gandy (41FK4), R. L. Cason (41MX1), Joe Justiss (41MX2), Hooper Glover (41MX4), Russell Bros. (41TT7), W. O. Reed (41UR1), and J. M. Riley (41UR2) sites.
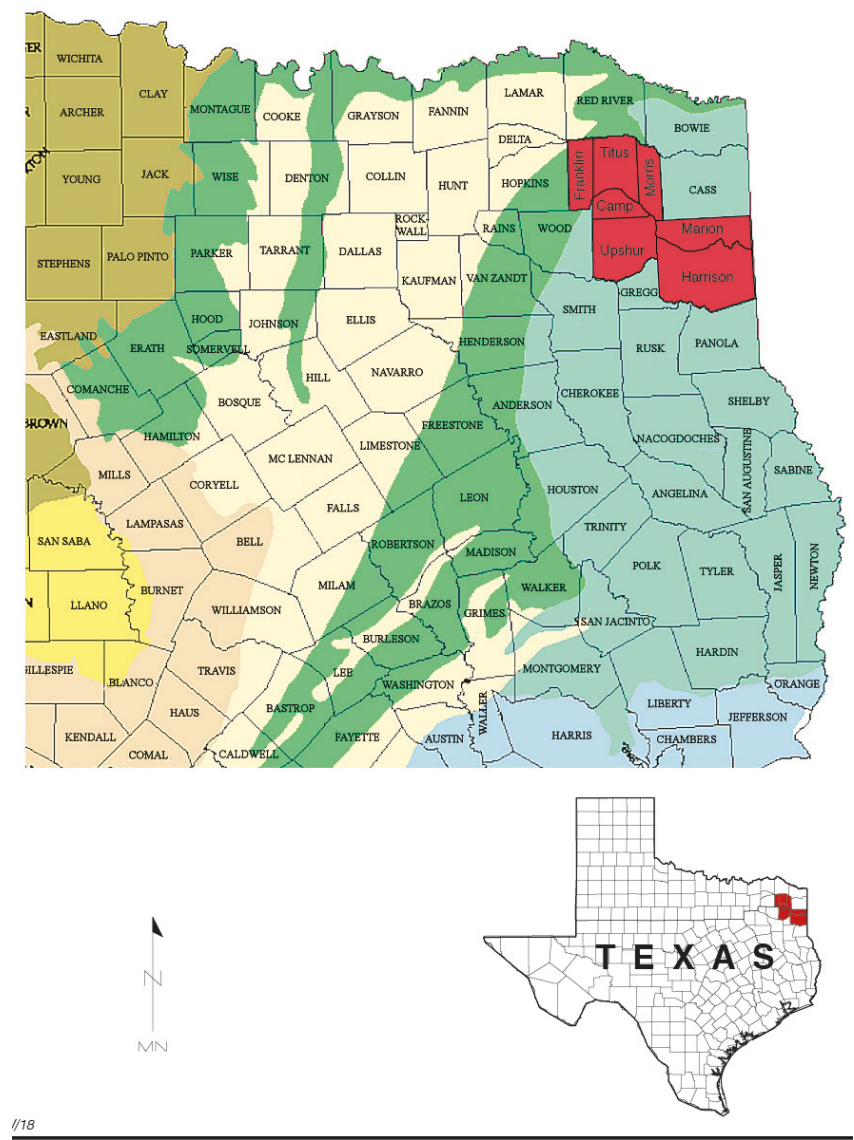

Figure 1. Counties in East Texas with ancestral Caddo sites with vessels documented in this study. 


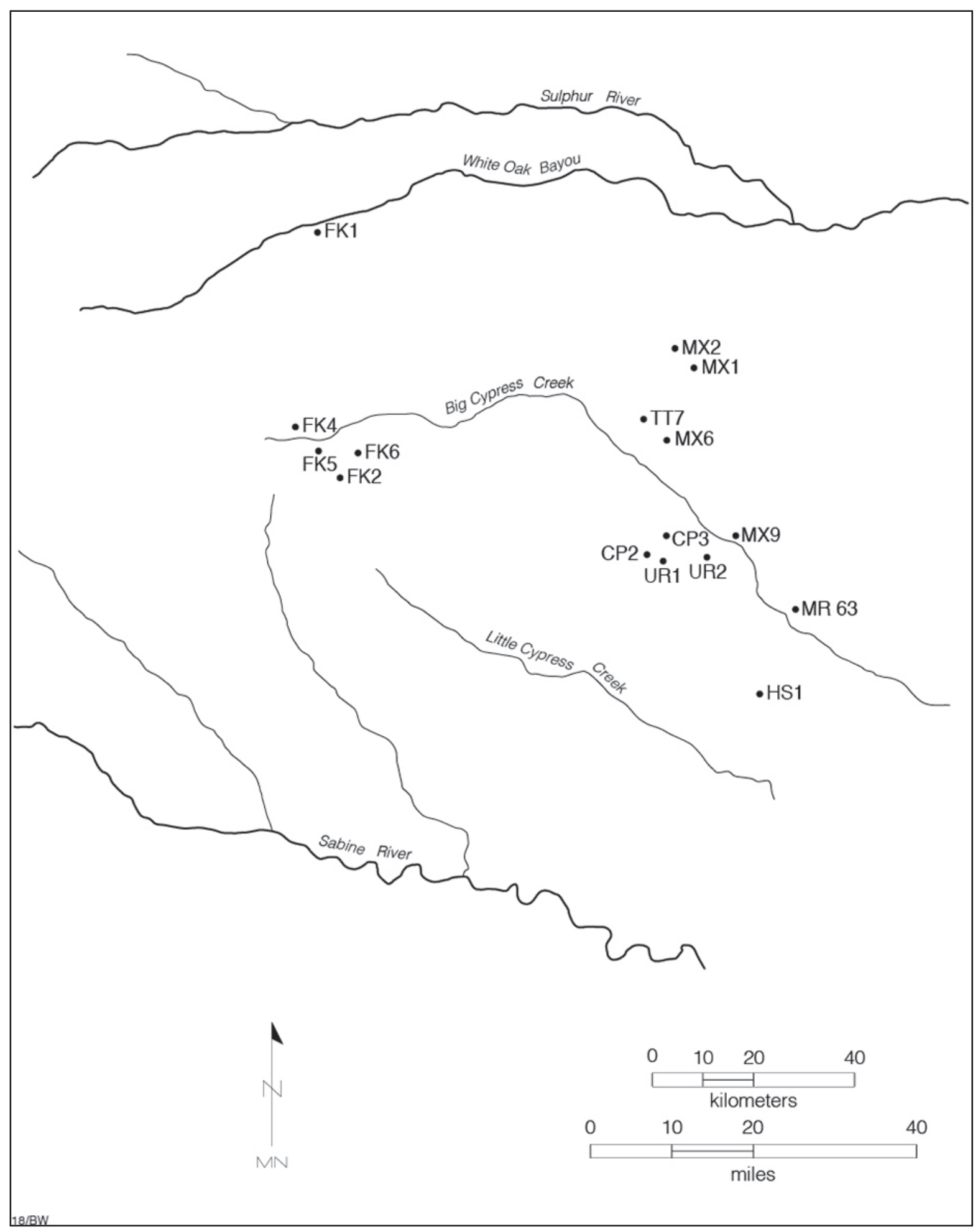

Figure 2. Location of selected Titus phase components with ceramic vessel assemblages in the Big Cypress Creek and Sulphur River basins in East Texas. 
Table 1. Ancestral Caddo ceramic vessels documented from the Texas Archeological Research Laboratory collections for this study.

\begin{tabular}{lccc}
\hline Site & Early Caddo period vessels & Late Caddo Titus phase vessels & N \\
\hline 41CP2 & - & 44 & 44 \\
41CP3 & - & 11 & 11 \\
41CP4 & - & 3 & 3 \\
41CP7 & - & 3 & 3 \\
41FK1 & - & 23 & 23 \\
41FK2 & 4 & 49 & 53 \\
41FK4 & - & 89 & 89 \\
41FK5 & - & 12 & 12 \\
41FK6 & - & 1 & 1 \\
41HS1 & - & 5 & 5 \\
41MR24 & - & 3 & 3 \\
41MR63 & - & 12 & 31 \\
41MX1 & - & 31 & 84 \\
41MX2 & - & 84 & 77 \\
41MX4 & - & 77 & 2 \\
41MX6 & - & 2 & 252 \\
41MX9 & - & 3 & 36 \\
41TT7 & - & 252 & 145 \\
41UR1 & - & 36 & 889 \\
41UR2 & - & 145 & \\
\hline Totals & 4 & 885 & \\
\hline
\end{tabular}

\section{The Character of Titus Phase Vessels}

\section{Vessel Wares in Titus Phase Components}

There are three wares in Titus phase vessel assemblages that have been recovered from burial features: plain ware, utility ware, and fine ware. In the larger vessel assemblages documented in this study, fine ware vessels comprise 67.5 percent of the sample (Table 2), followed by utility wares (26.6 percent), and plain ware (5.9 percent).

Table 2. Wares in the ceramic vessels from selected Titus phase vessel assemblages.

\begin{tabular}{lllll}
\hline Site & Plain Ware & Utility Ware & Fine Ware & N \\
\hline 41CP2 & 1 & 14 & 29 & 44 \\
41FK1 & - & 4 & 19 & 23 \\
41FK2 & - & 10 & 39 & 49 \\
41FK4 & 8 & 24 & 57 & 89 \\
41MX1 & 1 & 6 & 24 & 31 \\
41MX2 & 4 & 23 & 47 & 77 \\
41MX4 & 6 & 68 & 165 & 252 \\
41TT7 & 19 & 15 & 13 & 36 \\
41UR1 & 8 & 34 & 108 & 144 \\
41UR2 & 2 & 221 & 559 & 829 \\
\hline Totals & 49 & 26.6 & 67.5 & \\
Percent & 5.9 & & & \\
\hline
\end{tabular}


The proportion of fine wares in the various assemblages are highest (77-83 percent) in three sites in the White Oak Bayou and Big Cypress Creek basins, two in the western part of the two stream basins (Figure 3). The utility ware vessels are best represented in assemblages in two groups of sites in the eastern part of the Big Cypress Creek basin (Figure 3), while plain ware vessels are most abundant in assemblages in the western part of the White Oak Bayou and eastern parts of the Big Cypress Creek basin (Figure 3). Taken together, the proportional differences in vessel wares in these Titus phase assemblages suggest the existence of at least four spatial groupings of sites and burial features with associated ceramic vessel funerary offerings (see also below). These spatial groupings of sites and

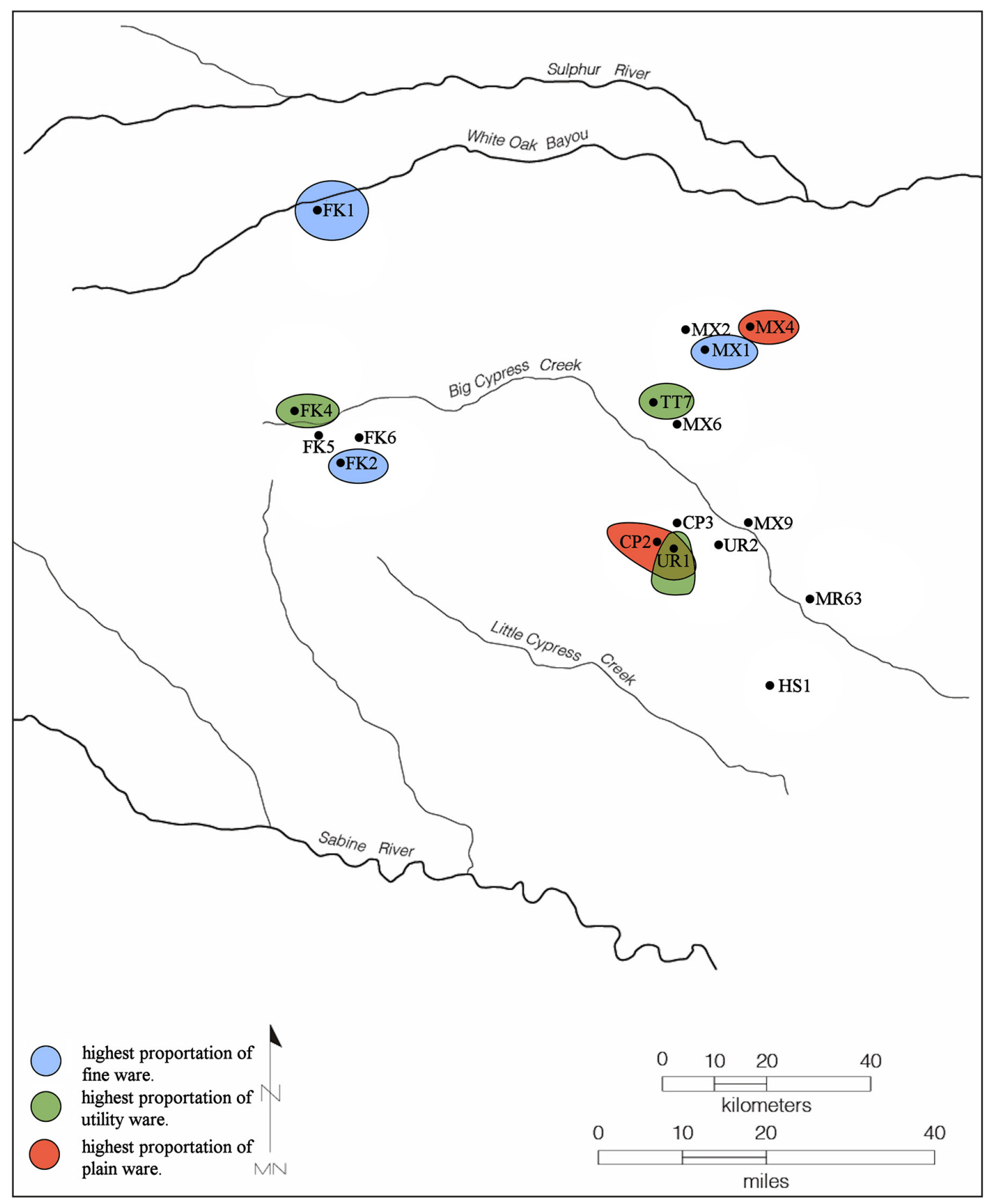

Figure 3. Distribution of Titus phase sites in the study area with the highest proportion of fine ware, utility ware, and plain ware vessels. 
ceramic assemblages correspond to at least two of the proposed Titus phase heartland communities in the Big Cypress Creek basin (see Fields et al. 2014:Figure 8.7), but the westernmost spatial groups on Big Cypress Creek and White Oak Bayou do not.

\section{Vessel Forms in Titus Phase Assemblages}

There are eight different vessel forms represented in the ceramic vessels from the Titus phase sites documented in this study (Table 3 ). The four most common forms include carinated bowls (43.9 percent), jars (30.2 percent), bottles (11.0 percent), and compound bowls ( 6.5 percent). The less common vessel forms - bowls, deep bowls, compound vessels, and ollas - together comprise only 8.4 percent of the assemblages (Table 3).

Table 3. Vessel forms in selected Titus phase assemblages.

\begin{tabular}{llllllllll}
\hline Site & Bt & CB & J & CPB & Bw & DB & CV & Ol & N \\
\hline 41CP2 & 7 & 20 & 13 & - & 4 & - & - & - & 44 \\
41FK1 & 4 & 14 & 4 & 1 & - & - & - & - & 23 \\
41FK2 & 4 & 25 & 11 & 4 & - & 5 & - & - & 49 \\
41FK4 & 8 & 46 & 24 & 5 & 2 & 3 & - & - & 88 \\
41MX1 & 6 & 18 & 6 & 1 & - & - & - & - & 31 \\
41MX2 & 10 & 43 & 23 & 3 & 1 & 2 & 1 & 1 & 84 \\
41MX4 & 15 & 23 & 26 & 5 & 1 & 1 & 1 & 4 & 76 \\
41TT7 & 22 & 96 & 85 & 28 & 17 & 2 & - & 2 & \\
252 & 6 & 6 & 18 & 2 & 4 & - & - & - & 36 \\
41UR1 & 9 & 71 & 40 & 5 & $6 *$ & 4 & 3 & 5 & 143 \\
41UR2 & 91 & 362 & 250 & 54 & 35 & 17 & 5 & 12 & 826 \\
\hline Totals & 11.0 & 43.9 & 30.2 & 6.5 & 4.2 & 2.1 & 0.6 & 1.5 & \\
Percent & & & & & & & & & \\
\end{tabular}

*includes three pigment vessels and one effigy bowl

$\mathrm{Bt}=$ bottle; $\mathrm{CB}=$ carinated bowl; $\mathrm{J}=$ jar; $\mathrm{CPB}=$ compound bowl; $\mathrm{Bw}=$ bowl; $\mathrm{DB}=$ deep bowl; $\mathrm{Cv}=$ compound vessel; $\mathrm{Ol}=\mathrm{olla}$

The highest proportion of carinated bowls and bottles in the assemblages are in sites in the northern part of the Big Cypress Creek basin, two sites in the southern part of the basin, and in one site in the White Oak Bayou basin (Figure 4). Jars are most frequent in vessel assemblages from eastern Big Cypress Creek Titus phase sites, while compound bowls are more common in sites in the middle and western parts of the Big Cypress Creek basin (Figure 4).

Deep bowls are most abundant in western Big Cypress Creek basin Titus phase sites, while ollas are more common in sites in the eastern and northern parts of the Big Cypress Creek basin (Figure 5). Compound vessels - i.e., conjoined vessels of different forms - are only relatively well represented at the J. M. Riley site (41UR2) in the eastern part of the Big Cypress Creek basin. The highest proportion of bowls in these vessel assemblages are in two other sites in the eastern part of the Big Cypress Creek basin (Figure 5). 


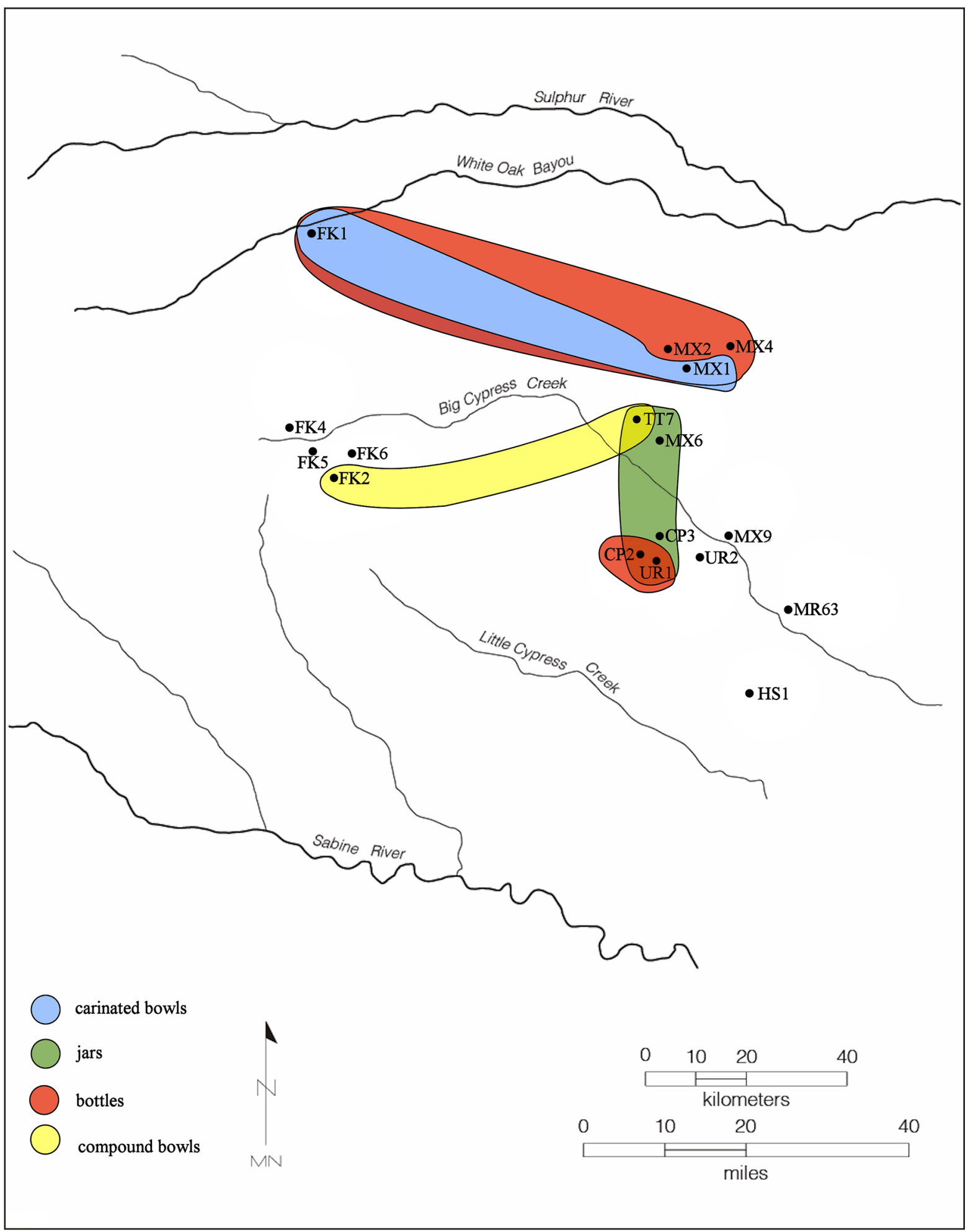

Figure 4. Highest proportions of carinated bowls, jars, bottles, and compound bowls in selected Titus phase vessel assemblages. 


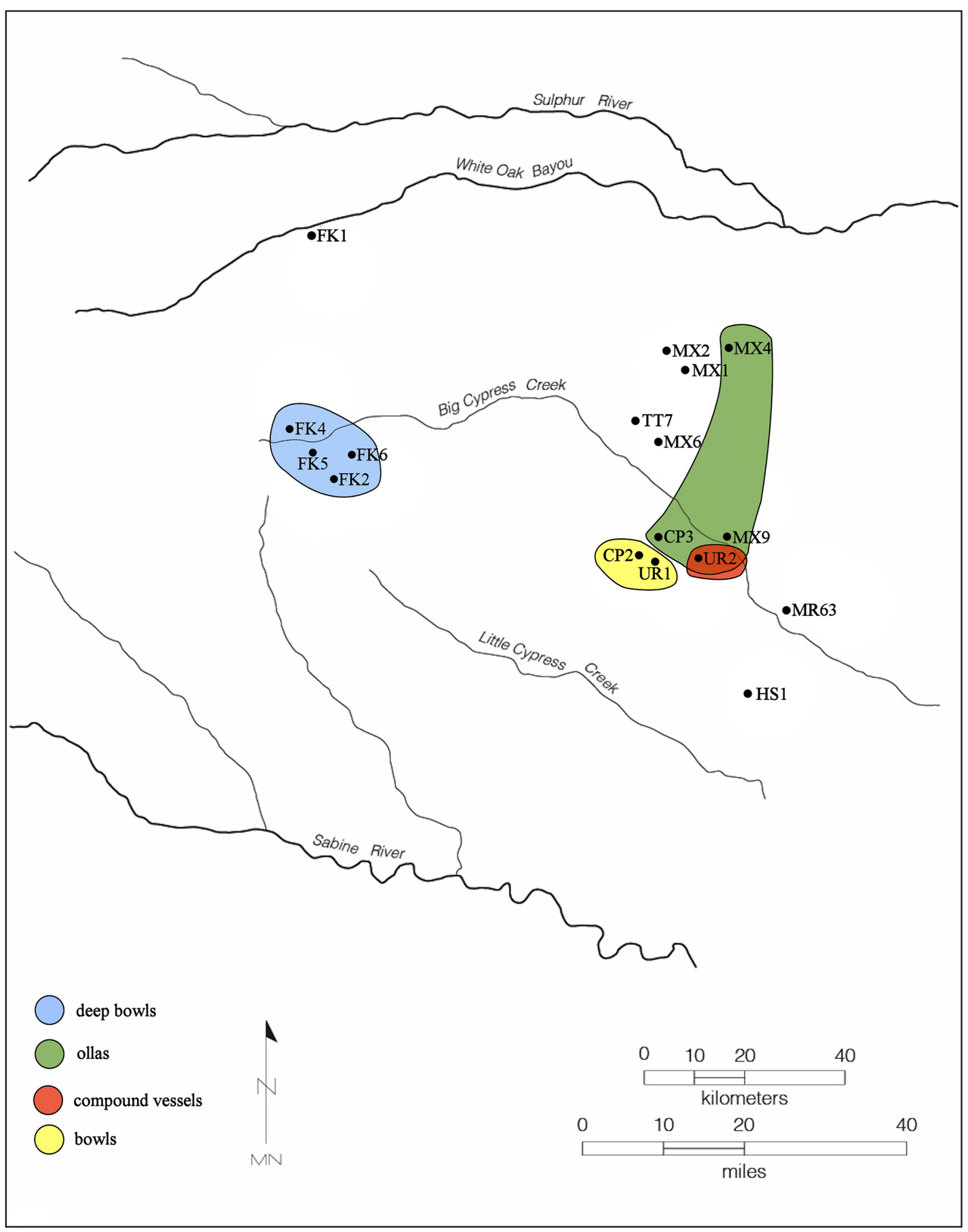

Figure 5. Highest proportions of deep bowls, ollas, bowls, and compound vessels in selected Titus phase vessel assemblages. 


\section{Use of Tempers in Titus Phase Vessel Manufacture}

Grog (i.e., crushed sherds) was the preferred temper used by Titus phase Caddo potters in the study area, as 71.6 percent of the vessel assemblage has grog temper (Table 4). Another 22.7 percent of the vessels are grog-tempered along with bone and/or hematite-temper.

Table 4. Temper use in ceramic vessels in selected Titus phase vessel assemblages.

\begin{tabular}{lllllllll}
\hline Site & G & G-H & G-B & B & G-H-B & B-H & SH & N \\
\hline 41CP2 & 37 & 3 & 1 & 1 & - & - & - & 42 \\
41FK1 & 19 & 2 & - & - & - & - & 2 & 23 \\
41FK2 & 39 & 4 & 2 & - & - & - & 4 & 49 \\
41FK4 & 70 & 16 & 2 & - & - & - & 1 & 89 \\
41MX1 & 17 & - & 11 & 2 & - & - & 1 & 31 \\
41MX2 & 51 & 7 & 14 & 2 & 5 & 1 & 4 & 84 \\
41MX4 & 62 & 5 & 6 & 2 & - & - & 2 & 77 \\
41TT7 & 180 & 38 & 17 & 8 & 5 & 1 & 3 & 252 \\
41UR1 & 21 & 7 & 4 & 3 & 1 & - & - & 36 \\
41UR2 & 96 & 31 & 8 & 3 & - & 1 & 5 & 144 \\
\hline Totals & 592 & 113 & 65 & 21 & 11 & 3 & 22 & 827 \\
Percent & 71.6 & 13.7 & 7.7 & 2.5 & 1.3 & 0.4 & 2.7 & \\
\hline
\end{tabular}

$\mathrm{G}=$ grog; $\mathrm{G}-\mathrm{H}=$ grog-hematite; $\mathrm{G}-\mathrm{B}=$ grog-bone; $\mathrm{B}=$ =bone; $\mathrm{G}-\mathrm{H}-\mathrm{B}=$ grog-hematite-bone; $\mathrm{B}-\mathrm{H}=$ =bone-hematite; $\mathrm{SH}=$ shell

Vessels with hematite temper inclusions, either in combination with grog, bone, or grog and bone, were used in 15.4 percent of the Titus phase vessels, and vessels with burned bone temper, as the sole temper as well as in combination with grog or hematite, comprise 11.9 percent of the vessel assemblage (see Table 4). Vessels of non-local origin (i.e., on the Red River in McCurtain phase communities) manufactured with burned mussel shell account for 2.7 percent of the Titus phase vessel assemblage.

The highest proportion of Titus phase vessels with grog temper are in western, northern, and eastern sites in the study area (Figure 6). Grog-hematite-tempered vessels are best represented in western and eastern Big Cypress Creek sites, while grog-bone-tempered vessels are most abundant in the northern Big Cypress Creek sites.

Shell-tempered vessels are most common in western Titus phase sites in the White Oak Bayou and Big Cypress Creek basins (Figure 7). Both grog-hematite-bone-tempered and bone-tempered vessels are best represented in eastern and northern Titus phase sites in the study area. 


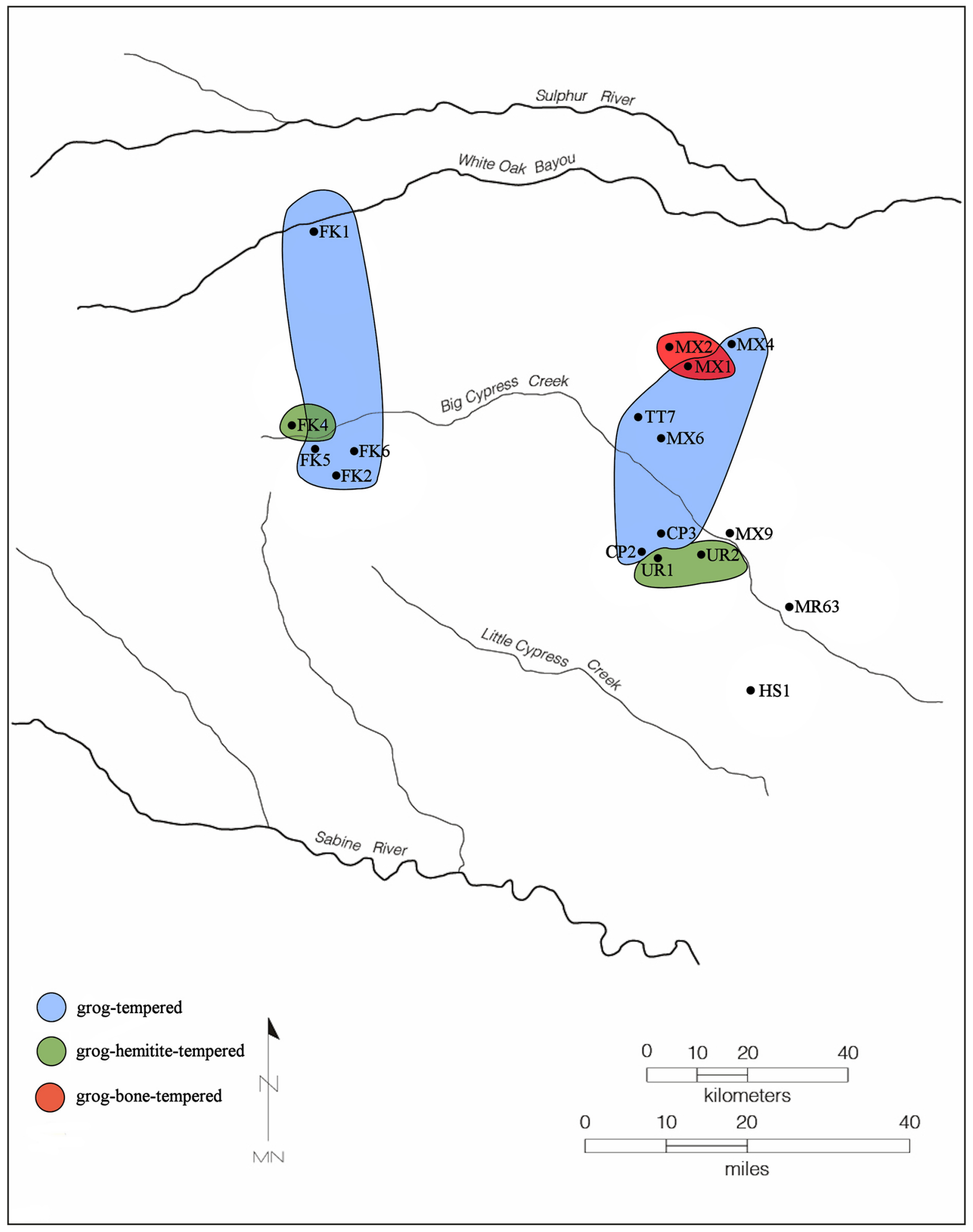

Figure 6. Highest proportions of grog-tempered, grog-hematite-tempered, and grog-bone-tempered vessels in selected Titus phase vessel assemblages. 


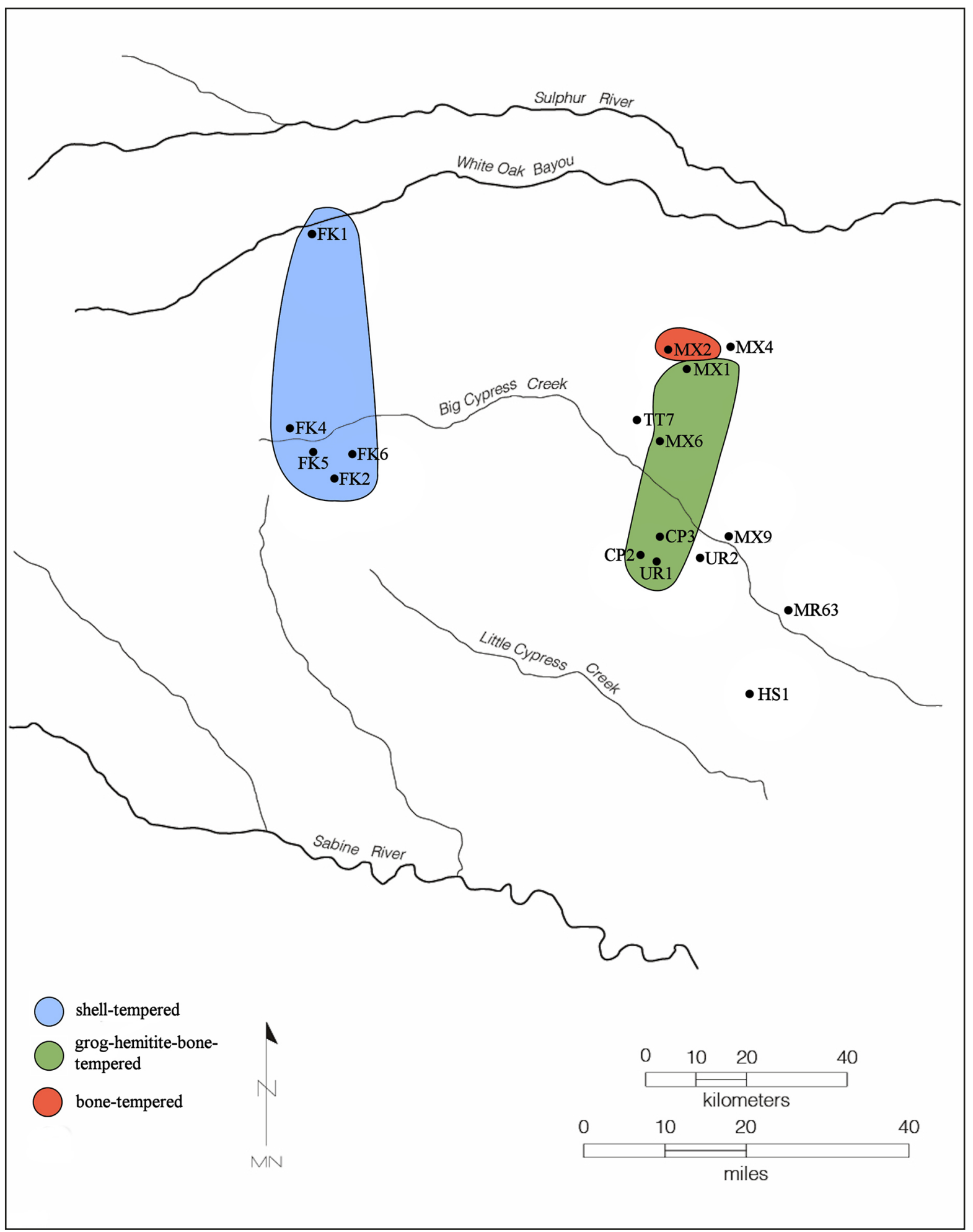

Figure 7. Highest proportions of shell-tempered, grog-hematite-bone-tempered, and bone-tempered vessels in selected Titus phase vessel assemblages. 


\section{Vessel Sizes (in Liters)}

In addition to manufacturing vessels in a variety of forms, Titus phase potters made vessels of different sizes within each of the recognized forms. These size differences in the vessels likely relate to "variation in activities connected with their use and eventual discard" as well as to "various purposes like cooking, storage, and display" (Shott 2018:1).

In the case of the carinated bowls, the Titus phase potters made them in four size ranges (Table 5). The principal size peak is between 0.1-1.6 liters, as more than 64 percent of the carinated bowls fall in this small to moderate volume range. A second but lesser peak (17.9 percent) of the carinated bowl volumes is between 3.2-4.0 liters. Even larger carinated bowls occur in the assemblages, with volumes ranging from 4.0-5.6 liters, but such vessels only account for 4.1 percent of the vessel assemblages (Table 5). Moderate to large carinated bowls with volumes ranging between 1.6-3.2 liters comprise 13.8 percent of the vessel assemblages in these Titus phase sites.

Table 5. Sizes (in liters) of carinated bowls in selected Titus phase vessel assemblages.

\begin{tabular}{lll}
\hline Range (in Liters) & No. & Percent \\
\hline $0.1-0.4$ & 32 & 9.4 \\
$0.4-0.8$ & 95 & 27.9 \\
$0.8-1.2$ & 57 & 16.7 \\
$1.2-1.6$ & 35 & 10.3 \\
& & \\
$1.6-2.0$ & 19 & 5.6 \\
$2.0-2.4$ & 8 & 2.3 \\
$2.4-2.8$ & 7 & 2.1 \\
$2.8-3.2$ & 13 & 3.8 \\
& & 10.3 \\
$3.2-3.6$ & 35 & 7.6 \\
$3.6-4.0$ & 26 & 2.6 \\
$4.0-4.4$ & & 1.2 \\
$4.4-4.8$ & 9 & - \\
$4.8-5.2$ & 4 & 0.3 \\
$5.2-5.6$ & - & \\
\hline Totals & 1 & \\
\hline
\end{tabular}

The largest vessels made and used by Titus phase potters in these assemblages include a number of jars, almost all utility wares, with volumes ranging from 5.3-12.8 liters (Table 6), although these represent only 10.1 percent of the jars from the sites. Instead, most of the jars placed in burial features at the sites are small to moderate in size (0.1-1.6 liters), accounting for 56.6 percent of the jars in the assemblages. Smaller groups of jars are moderate to large in size (1.6-3.6 liters), accounting for 27.5 percent of the sample, or large in size (3.6-5.2 liters). This group of jars represents only 5.9 percent of the Titus phase jar assemblage (Table 6). 
Table 6. Sizes (in liters) of jars in selected Titus phase vessel assemblages.

\begin{tabular}{|c|c|c|}
\hline Range (in Liters) & No. & Percent \\
\hline $0.1-0.4$ & 6 & 2.9 \\
\hline $0.4-0.8$ & 28 & 13.6 \\
\hline $0.8-1.2$ & 58 & 28.0 \\
\hline $1.2-1.6$ & 25 & 12.1 \\
\hline $1.6-2.0$ & 6 & 2.9 \\
\hline $2.0-2.4$ & 17 & 8.2 \\
\hline $2.4-2.8$ & 16 & 7.7 \\
\hline $2.8-3.2$ & 12 & 5.8 \\
\hline $3.2-3.6$ & 6 & 2.9 \\
\hline $3.6-4.0$ & 2 & 1.0 \\
\hline $4.0-4.4$ & 1 & 0.5 \\
\hline $4.4-4.8$ & 6 & 2.9 \\
\hline $4.8-5.2$ & 3 & 1.5 \\
\hline $5.2-5.6$ & - & - \\
\hline $5.6-6.0$ & 1 & 0.5 \\
\hline $6.0-6.4$ & 1 & 0.5 \\
\hline $6.4-6.8$ & - & - \\
\hline $6.8-7.2$ & 3 & 0.5 \\
\hline 7.2-7.6 & 1 & 0.5 \\
\hline 7.6-8.0 & 3 & 1.5 \\
\hline $8.0-8.4$ & 1 & 0.5 \\
\hline $8.4-8.8$ & 1 & 0.5 \\
\hline $8.8-9.2$ & 3 & 1.5 \\
\hline $9.2-9.6$ & 1 & 0.5 \\
\hline $9.6-10.0$ & 1 & 0.5 \\
\hline $10.0-10.4$ & 1 & 0.5 \\
\hline $10.4-10.8$ & - & - \\
\hline $10.8-11.2$ & - & - \\
\hline $11.2-11.6$ & 3 & 1.5 \\
\hline $11.6-12.0$ & - & - \\
\hline $12.0-12.4$ & - & - \\
\hline $12.4-12.8$ & 1 & 0.5 \\
\hline Totals & 207 & \\
\hline
\end{tabular}

The compound bowls from the Titus phase vessel assemblages fall into three size groups: 0.1-1.6 liters or small to moderate in size, 1.6-3.6 liters or moderate to large in size, and 4.8-9.2 liters or large to very large in size (Table 7). The small to moderate-sized compound bowls comprise 46.9 percent of the compound bowl sample, and the moderate to large compound bowls represent only 10.1 percent of the assemblage. The large to very large compound bowls represent 42.8 percent of these vessels, almost the same proportion as the small to moderately-sized compound bowls (Table 7). 
Table 7. Sizes (in liters) of compound bowls in selected Titus phase vessel assemblages.

\begin{tabular}{lll}
\hline Range (in Liters) & No. & Percent \\
\hline $0.1-0.4$ & 2 & 4.1 \\
$0.4-0.8$ & 7 & 14.3 \\
$0.8-1.2$ & 8 & 16.3 \\
$1.2-1.6$ & 6 & 12.2 \\
$1.6-2.0$ & 1 & 2.0 \\
$2.0-2.4$ & 1 & 2.0 \\
$2.4-2.8$ & - & - \\
$2.8-3.2$ & 1 & 2.0 \\
$3.2-3.6$ & 2 & 4.1 \\
$3.6-4.0$ & - & - \\
$4.0-4.4$ & - & - \\
$4.4-4.8$ & - & - \\
$4.8-5.2$ & & 4.1 \\
$5.2-5.6$ & 2 & 8.2 \\
$5.6-6.0$ & & 4.1 \\
$6.0-6.4$ & 4 & 2.0 \\
$6.4-6.8$ & 2 & 8.2 \\
$6.8-7.2$ & 1 & 4.1 \\
$7.2-7.6$ & 4 & 4.1 \\
$7.6-8.0$ & 2 & 2.0 \\
$8.0-8.4$ & 2 & 2.0 \\
$8.4-8.8$ & 1 & 2.0 \\
$8.8-9.2$ & 1 & 2.0 \\
\hline Totals & 1 & \\
\hline & 1 & \\
\hline
\end{tabular}

Bottles and bowls in the Titus phase vessel assemblages tend to have small volumes (less than 0.4 liters). More than 64.5 percent of the bottles at the sites are less than 0.4 liters in volume, and 72.2 percent of the bowls are less than 0.4 liters in volume (Table 8). Only 1.4 percent of the bottles and 5.6 percent of the bowls are more than 0.8 liters in volume.

Table 8. Sizes (in liters) of bottles and bowls in selected Titus phase vessel assemblages.

\begin{tabular}{lllll}
\hline Range (in Liters) & $\begin{array}{l}\text { Bottles } \\
\text { No. }\end{array}$ & Percent & $\begin{array}{l}\text { Bowls } \\
\text { No. }\end{array}$ & Percent \\
\hline $0.1-0.2$ & 14 & 18.9 & 16 & 44.4 \\
$0.2-0.4$ & 34 & 45.9 & 10 & 27.8 \\
$0.4-0.6$ & 13 & 17.7 & 5 & 13.9 \\
$0.6-0.8$ & 12 & 16.2 & 3 & 8.3 \\
$0.8-1.0$ & 1 & 1.4 & 1 & 2.8 \\
$1.0-1.2$ & - & - & 1 & 2.8 \\
\hline Totals & 74 & & 36 & \\
\hline
\end{tabular}


Deep bowls in these Titus phase vessel assemblages occur in two size groups: 0.4-2.0 liters, small to moderate in size, and 2.8-4.4 liters, large in size (Table 9). Most of the ollas have volumes that range from 1.6-2.0 liters, but comprise a single size group with volumes between 1.2-2.8 liters. Compound vessels are small to moderate in size (Table 9).

Table 9. Sizes (in liters) of deep bowls, ollas, and compound vessels in selected Titus phase vessel assemblages.

\begin{tabular}{lllllll}
\hline \multirow{2}{*}{$\begin{array}{l}\text { Range } \\
\text { (in Liters) }\end{array}$} & \multicolumn{2}{c}{ Deep Bowls } & \multicolumn{2}{c}{ Ollas } & \multicolumn{2}{c}{ Compound Vessels } \\
& No. & Percent & No. & Percent & No. & Percent \\
\hline $0.1-0.4$ & - & - & - & - & 1 & 20.0 \\
$0.4-0.8$ & 1 & 7.1 & - & - & 3 & 60.0 \\
$0.8-1.2$ & 4 & 28.7 & - & - & 1 & 20.0 \\
$1.2-1.6$ & 2 & 14.3 & 1 & 14.3 & - & - \\
$1.6-2.0$ & 3 & 21.4 & 4 & 57.1 & - & - \\
$2.0-2.4$ & - & - & 1 & 14.3 & - & - \\
$2.4-2.8$ & - & - & 1 & 14.3 & - & - \\
$2.8-3.2$ & 1 & 7.1 & - & - & - & - \\
$3.2-3.6$ & 1 & 7.1 & - & - & - & - \\
$3.6-4.0$ & 1 & 7.1 & - & - & - & - \\
$4.0-4.4$ & 1 & 7.1 & - & - & 5 & \\
\hline Totals & 14 & & 7 & & \\
\hline
\end{tabular}

\section{Fine Ware Types and Varieties}

There is considerable diversity in the identified fine ware types in these selected Titus phase assemblages (Table 10), including a few vessels (5.5 percent) that are of non-local manufacture, having been made, traded, or exchanged by contemporaneous McCurtain phase, Belcher phase, and Frankston phase potters living on the Red River to the north and east of these Titus phase sites, or living in the upper Neches River basin to the south. Approximately 78.4 percent of the identified fine ware types and varieties are Ripley Engraved vessels, particularly var. Galt (13.0 percent of the identified fine wares), var. Gandy (13.0 percent), var. McKinney (12.6 percent), var. Carpenter (8.4 percent), and var. GandyPine Tree (7.5 percent) (Figure 8a-e).

Table 10. Fine ware types and varieties in selected Titus phase ceramic assemblages.

\begin{tabular}{lllll}
\hline Type-Variety & $41 \mathrm{CP} 2$ & $41 \mathrm{FK} 1$ & $41 \mathrm{FK} 2$ & $41 \mathrm{FK} 4$ \\
\hline Avery Engraved* & - & - & 6 & 1 \\
Bailey Engraved & 3 & - & - & - \\
Belcher Engraved* & - & - & - & - \\
Bowie Engraved* & - & - & - & - \\
Glassell Engraved* & - & - & - & - \\
Hodges Engraved* & - & - & - & - \\
Hood Engraved* & - & - & - & - \\
Keno Trailed* & - & - & - & - \\
Poynor Engraved* & - & 2 & - & - \\
Ripley Engraved, var. Caldwell & - & & &
\end{tabular}


Table 10. Fine ware types and varieties in selected Titus phase ceramic assemblages, cont.

\begin{tabular}{|c|c|c|c|c|}
\hline Type-Variety & $41 \mathrm{CP} 2$ & $41 \mathrm{FK} 1$ & $41 \mathrm{FK} 2$ & 41FK4 \\
\hline Ripley Engraved, var. Carpenter & - & 4 & 2 & 2 \\
\hline Ripley Engraved, var. Cash & 1 & - & - & - \\
\hline Ripley Engraved, var. Galt & - & 4 & 10 & 9 \\
\hline $\begin{array}{l}\text { Ripley Engraved, var. Galt- } \\
\text { Carpenter }\end{array}$ & - & - & - & - \\
\hline $\begin{array}{l}\text { Ripley Engraved, var. Galt- } \\
\text { McKinney }\end{array}$ & - & - & - & - \\
\hline Ripley Engraved, var. Gandy & 3 & 1 & 9 & 14 \\
\hline $\begin{array}{l}\text { Ripley Engraved, var. Gandy- } \\
\text { McKinney }\end{array}$ & - & - & - & - \\
\hline $\begin{array}{l}\text { Ripley Engraved, var. Gandy- } \\
\text { Mockingbird }\end{array}$ & - & - & - & 2 \\
\hline $\begin{array}{l}\text { Ripley Engraved, var. Gandy- } \\
\text { Pine Tree }\end{array}$ & 1 & - & - & 11 \\
\hline $\begin{array}{l}\text { Ripley Engraved, var. Gandy- } \\
\text { Pine Tree-Ripley }\end{array}$ & - & - & - & - \\
\hline Ripley Engraved, var. Harvard & - & - & - & - \\
\hline Ripley Engraved, var. McKinney & 6 & - & - & - \\
\hline $\begin{array}{l}\text { Ripley Engraved, var. McKinney- } \\
\text { Enis Smith }\end{array}$ & 3 & - & - & - \\
\hline Ripley Engraved, var. Pilgrims & 1 & - & - & - \\
\hline Ripley Engraved, var. Reed & - & - & - & - \\
\hline Ripley Engraved, var. Richey & - & - & - & - \\
\hline Ripley Engraved, var. Ripley & - & - & 2 & 5 \\
\hline Ripley Engraved, var. Russell & - & - & - & - \\
\hline Ripley Engraved, var. Tiddle & - & - & - & 1 \\
\hline Ripley Engraved, var. Williams & - & - & 1 & - \\
\hline Simms Engraved* & - & 2 & - & - \\
\hline Taylor Engraved & 6 & 1 & - & - \\
\hline Turner Engraved, var. Horton & - & - & - & - \\
\hline Turner Engraved, var. Turner & - & - & - & - \\
\hline Wilder Engraved, var. Ebenezer & - & - & - & 2 \\
\hline Wilder Engraved, var. Wilder & 1 & - & 1 & - \\
\hline Totals & 26 & 14 & 30 & 47 \\
\hline
\end{tabular}

*non-locally manufactured fine ware types 
Table 10. Fine ware types and varieties in selected Titus phase ceramic assemblages, cont.

\begin{tabular}{|c|c|c|c|c|}
\hline Type-Variety & $41 \mathrm{MX} 1$ & $41 \mathrm{MX} 2$ & $41 \mathrm{MX} 4$ & $41 \mathrm{TT7}$ \\
\hline Avery Engraved* & - & - & - & 2 \\
\hline Bailey Engraved & - & - & 4 & - \\
\hline Belcher Engraved* & - & - & - & - \\
\hline Bowie Engraved* & - & 1 & - & - \\
\hline Glassell Engraved* & - & - & - & - \\
\hline Hodges Engraved* & - & - & - & - \\
\hline Hood Engraved* & - & - & - & 3 \\
\hline Keno Trailed* & 1 & - & - & - \\
\hline Poynor Engraved* & - & - & - & - \\
\hline Ripley Engraved, var. Caldwell & - & 3 & 1 & 2 \\
\hline Ripley Engraved, var. Carpenter & - & - & - & 28 \\
\hline Ripley Engraved, var. Cash & 1 & 2 & 2 & 3 \\
\hline Ripley Engraved, var. Galt & 1 & 1 & 1 & 25 \\
\hline $\begin{array}{l}\text { Ripley Engraved, var. Galt- } \\
\text { Carpenter }\end{array}$ & - & - & - & 1 \\
\hline $\begin{array}{l}\text { Ripley Engraved, var. Galt- } \\
\text { McKinney }\end{array}$ & - & - & - & 1 \\
\hline Ripley Engraved, var. Gandy & 9 & 10 & 1 & 6 \\
\hline $\begin{array}{l}\text { Ripley Engraved, var. Gandy- } \\
\text { McKinney }\end{array}$ & - & - & - & 1 \\
\hline $\begin{array}{l}\text { Ripley Engraved, var. Gandy- } \\
\text { Mockingbird }\end{array}$ & - & 1 & - & - \\
\hline $\begin{array}{l}\text { Ripley Engraved, var. Gandy- } \\
\text { Pine Tree }\end{array}$ & - & 3 & 1 & 15 \\
\hline $\begin{array}{l}\text { Ripley Engraved, var. Gandy- } \\
\text { Pine Tree-Ripley }\end{array}$ & - & - & - & 1 \\
\hline Ripley Engraved, var. Harvard & - & - & - & - \\
\hline Ripley Engraved, var. McKinney & 3 & 6 & 3 & 18 \\
\hline $\begin{array}{l}\text { Ripley Engraved, var. McKinney- } \\
\text { Enis Smith }\end{array}$ & 1 & 6 & 5 & - \\
\hline Ripley Engraved, var. Pilgrims & - & 1 & - & 2 \\
\hline Ripley Engraved, var. Reed & - & - & - & - \\
\hline Ripley Engraved, var. Richey & 1 & 6 & 6 & 1 \\
\hline Ripley Engraved, var. Ripley & - & - & 1 & 2 \\
\hline Ripley Engraved, var. Russell & - & - & - & 8 \\
\hline Ripley Engraved, var. Tiddle & - & - & 1 & - \\
\hline Ripley Engraved, var. Williams & - & - & - & 1 \\
\hline Simms Engraved* & 1 & - & 1 & 4 \\
\hline Taylor Engraved & - & 2 & 2 & 1 \\
\hline Turner Engraved, var. Horton & - & - & 1 & 2 \\
\hline Turner Engraved, var. Turner & - & - & 1 & 5 \\
\hline Wilder Engraved, var. Ebenezer & 1 & 3 & 7 & 2 \\
\hline Wilder Engraved, var. Wilder & - & 3 & 1 & 7 \\
\hline Totals & 19 & 48 & 39 & 141 \\
\hline
\end{tabular}

*non-locally manufactured fine ware type 
Table 10. Fine ware types and varieties in selected Titus phase ceramic assemblages, cont.

\begin{tabular}{|c|c|c|c|c|}
\hline Type-Variety & 41UR1 & 41UR2 & $\mathrm{N}$ & Percent \\
\hline Avery Engraved* & - & 1 & 10 & 2.2 \\
\hline Bailey Engraved & - & - & 7 & 1.5 \\
\hline Belcher Engraved* & - & 3 & 3 & 0.7 \\
\hline Bowie Engraved* & - & 1 & 2 & 0.4 \\
\hline Glassell Engraved* & - & 1 & 1 & 0.2 \\
\hline Hodges Engraved* & - & 3 & 3 & 0.7 \\
\hline Hood Engraved* & - & 1 & 4 & 0.9 \\
\hline Keno Trailed* & - & - & 1 & 0.2 \\
\hline Poynor Engraved* & 1 & - & 1 & 0.2 \\
\hline Ripley Engraved, var. Caldwell & 1 & - & 9 & 2.0 \\
\hline Ripley Engraved, var. Carpenter & - & 2 & 38 & 8.4 \\
\hline Ripley Engraved, var. Cash & - & 2 & 11 & 2.4 \\
\hline Ripley Engraved, var. Galt & 1 & 7 & 59 & 13.0 \\
\hline $\begin{array}{l}\text { Ripley Engraved, var. Galt- } \\
\text { Carpenter }\end{array}$ & - & - & 1 & 0.2 \\
\hline $\begin{array}{l}\text { Ripley Engraved, var. Galt- } \\
\text { McKinney }\end{array}$ & - & - & 1 & 0.2 \\
\hline Ripley Engraved, var. Gandy & - & 6 & 59 & 13.0 \\
\hline $\begin{array}{l}\text { Ripley Engraved, var. Gandy- } \\
\text { McKinney }\end{array}$ & - & - & 1 & 0.2 \\
\hline $\begin{array}{l}\text { Ripley Engraved, var. Gandy- } \\
\text { Mockingbird }\end{array}$ & - & - & 3 & 0.7 \\
\hline $\begin{array}{l}\text { Ripley Engraved, var. Gandy- } \\
\text { Pine Tree }\end{array}$ & - & 3 & 34 & 7.5 \\
\hline \multicolumn{5}{|l|}{ Ripley Engraved, var. Gandy- } \\
\hline Pine Tree-Ripley & - & - & 1 & 0.2 \\
\hline Ripley Engraved, var. Harvard & - & 1 & 1 & 0.2 \\
\hline Ripley Engraved, var. McKinney & - & 21 & 57 & 12.6 \\
\hline $\begin{array}{l}\text { Ripley Engraved, var. McKinney- } \\
\text { Enis Smith }\end{array}$ & - & 11 & 26 & 5.7 \\
\hline Ripley Engraved, var. Pilgrims & - & 4 & 8 & 1.8 \\
\hline Ripley Engraved, var. Reed & 3 & - & 3 & 0.7 \\
\hline Ripley Engraved, var. Richey & - & 6 & 20 & 4.4 \\
\hline Ripley Engraved, var. Ripley & - & - & 10 & 2.2 \\
\hline Ripley Engraved, var. Russell & - & - & 8 & 1.8 \\
\hline Ripley Engraved, var. Tiddle & - & 1 & 3 & 0.7 \\
\hline Ripley Engraved, var. Williams & - & 3 & 5 & 1.1 \\
\hline Simms Engraved* & - & 2 & 10 & 2.2 \\
\hline Taylor Engraved & - & 8 & 20 & 4.4 \\
\hline Turner Engraved, var. Horton & - & - & 3 & 0.7 \\
\hline Turner Engraved, var. Turner & 1 & - & 7 & 1.5 \\
\hline Wilder Engraved, var. Ebenezer & - & 1 & 16 & 3.5 \\
\hline Wilder Engraved, var. Wilder & - & 5 & 18 & 4.0 \\
\hline Totals & 7 & 82 & 453 & \\
\hline
\end{tabular}

*non-locally manufactured fine ware type 

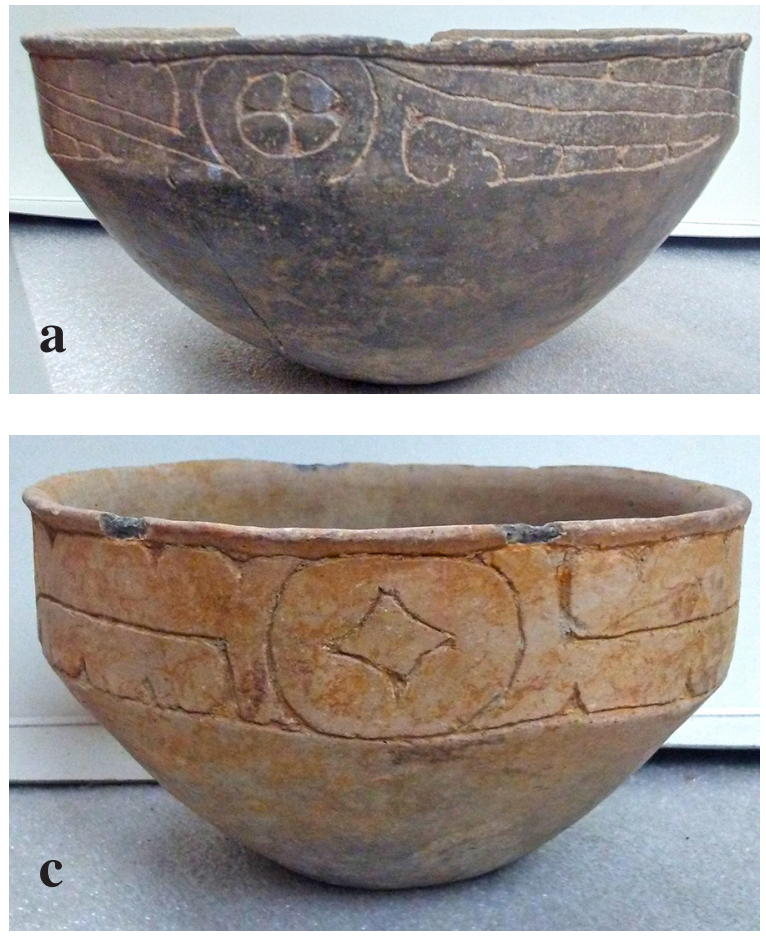
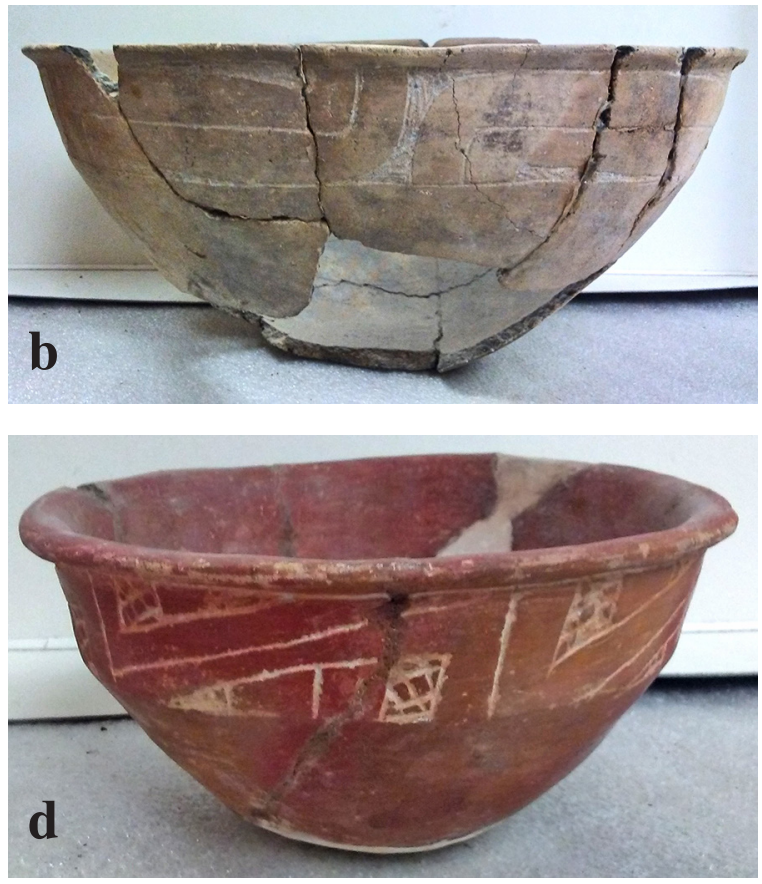

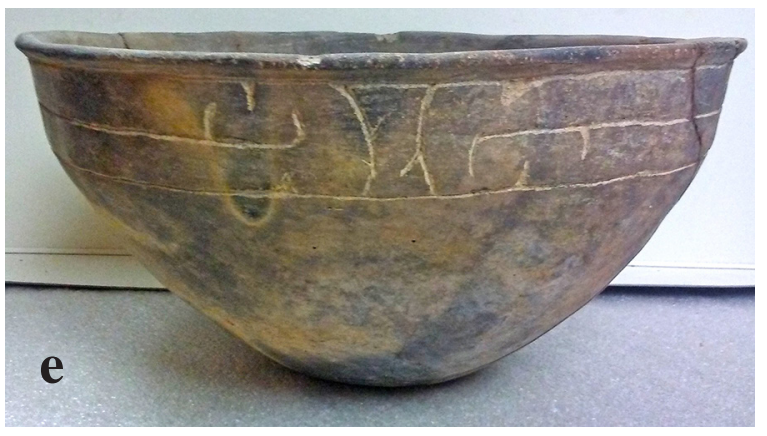

Figure 8. Principal Ripley Engraved varieties in the study area: a, var. Galt, Vessel 2 at 41MX9; b, var. Gandy, Vessel 296 at 41TT7; c, var. McKinney, Vessel 4 at 41UR2; d, var. Carpenter, Vessel 12 at 41CP3; e, var. GandyPine Tree, Vessel 73 at $41 \mathrm{MX} 4$.

These principal varieties of Ripley Engraved are not found in equal proportions in these Titus phase assemblages. Ripley Engraved, var. Galt vessels are most common in northern White Oak Bayou sites and western and northern Big Cypress Creek basin sites (Figure 9), while var. Gandy vessels are best represented in western and northern Big Cypress Creek sites. Ripley Engraved, var. McKinney vessels are concentrated in eastern Titus phase sites (Figure 9), and var. Carpenter vessels are best represented in White Oak Bayou and mid-Big Cypress Creek basin sites (Figure 9). The Ripley Engraved, var. Gandy-Pine Tree vessels are most common at the Mattie Gandy site (41FK4) in the upper part of the Big Cypress Creek basin.

The less common Ripley Engraved varieties are most abundant in northern, middle, and eastern Big Cypress Creek Titus phase sites (Figure 10). Ripley Engraved, var. Ripley bottles are best represented at the Mattie Gandy site in the upper Big Cypress Creek basin, and the var. Russell bottles occur at the Russell Bros site (41TT7). 


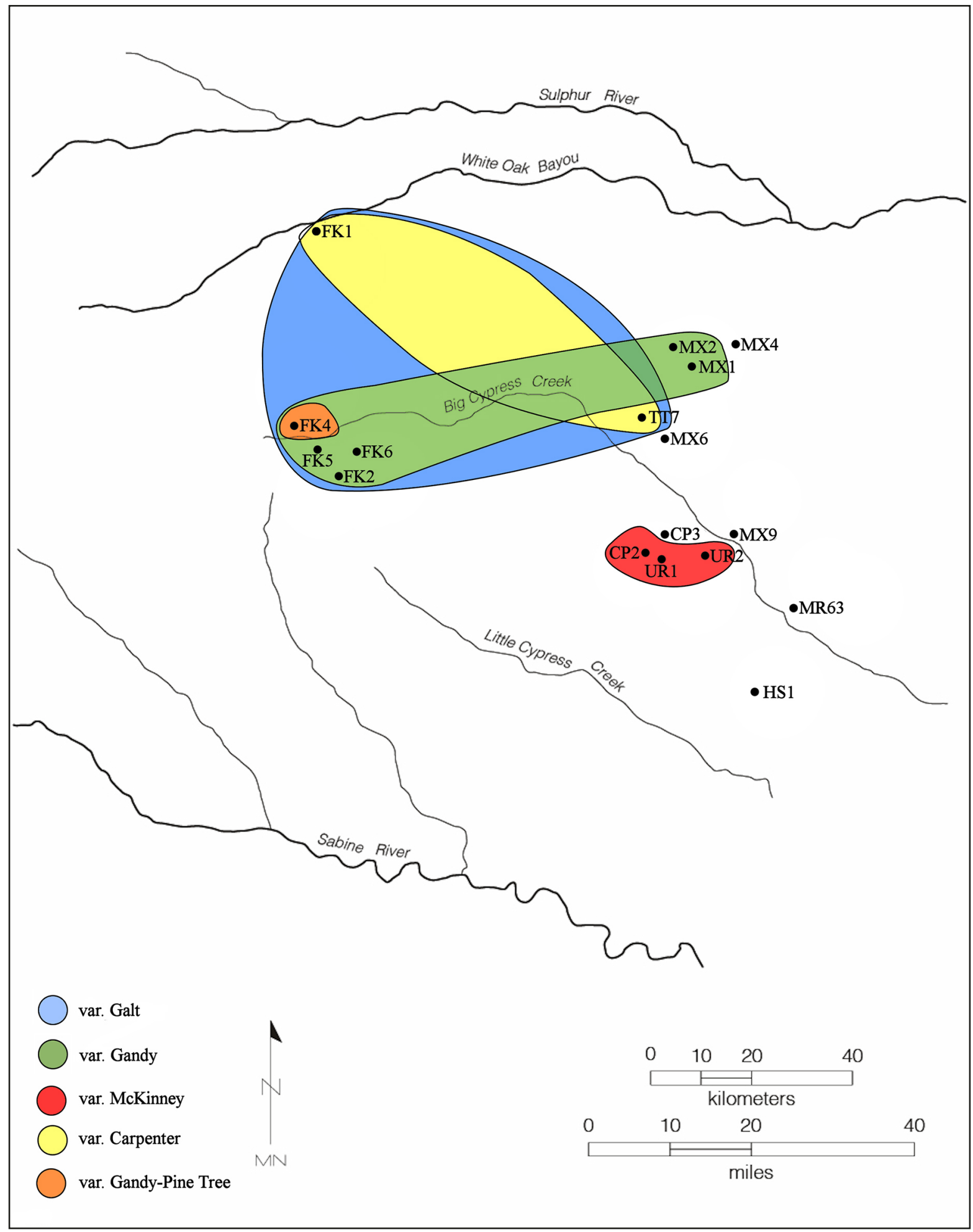

Figure 9. The distribution of sites with the highest proportion of Ripley Engraved, var. Galt, var. Gandy, var. McKinney, var. Carpenter, and var. Gandy-Pine Tree vessels in selected Titus phase assemblages. 


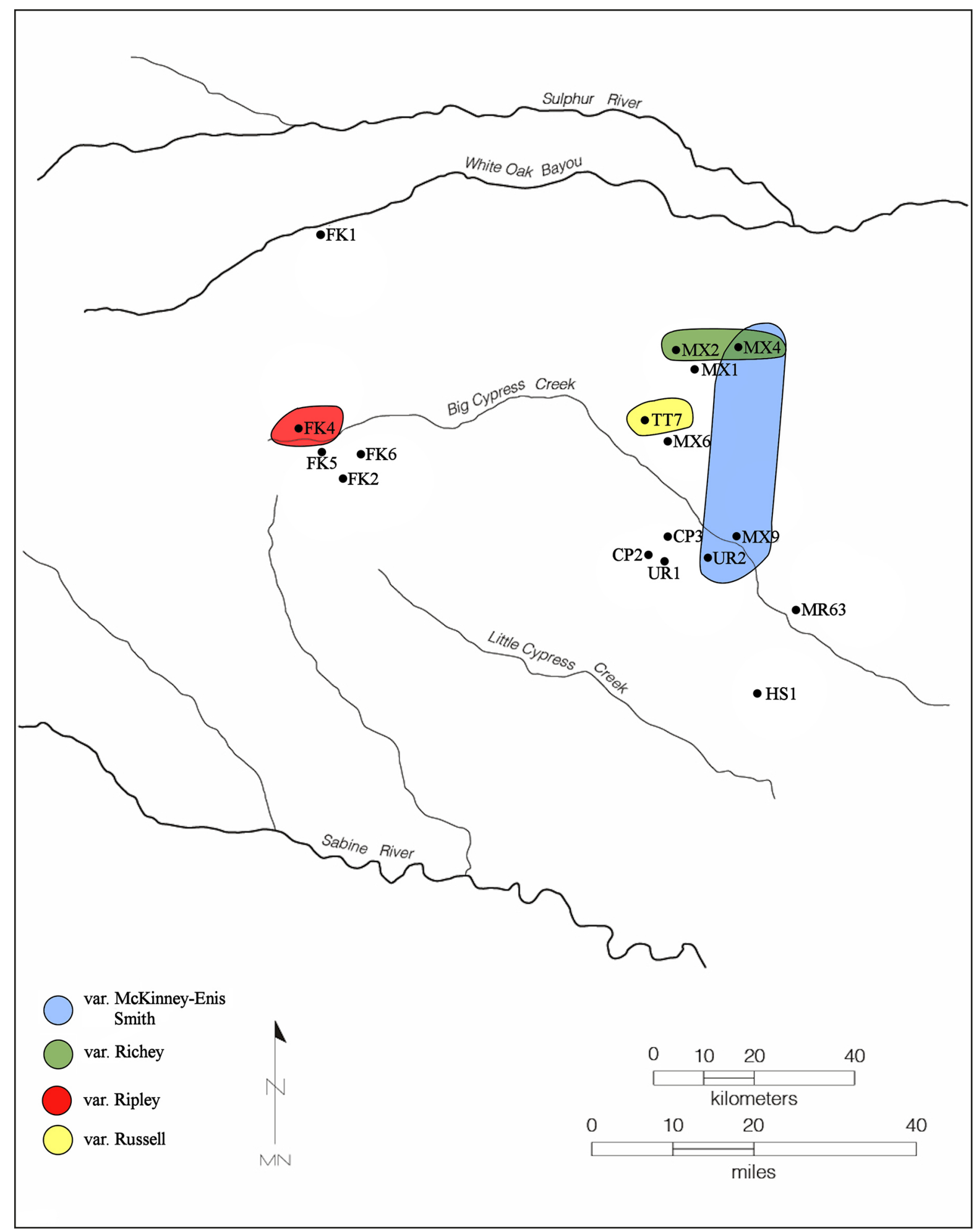

Figure 10. The distribution of sites with the highest proportion of Ripley Engraved, var. McKinney-Enis Smith, var. Richey, var. Ripley, and var. Russell vessels in selected Titus phase assemblages. 
The highest proportion of Turner Engraved and Wilder Engraved varieties in the Titus phase sites occur in the northern and eastern Big Cypress Creek basin (Figure 11). These are somewhat common Titus phase fine wares in the studied assemblages (Figure 12a-b).

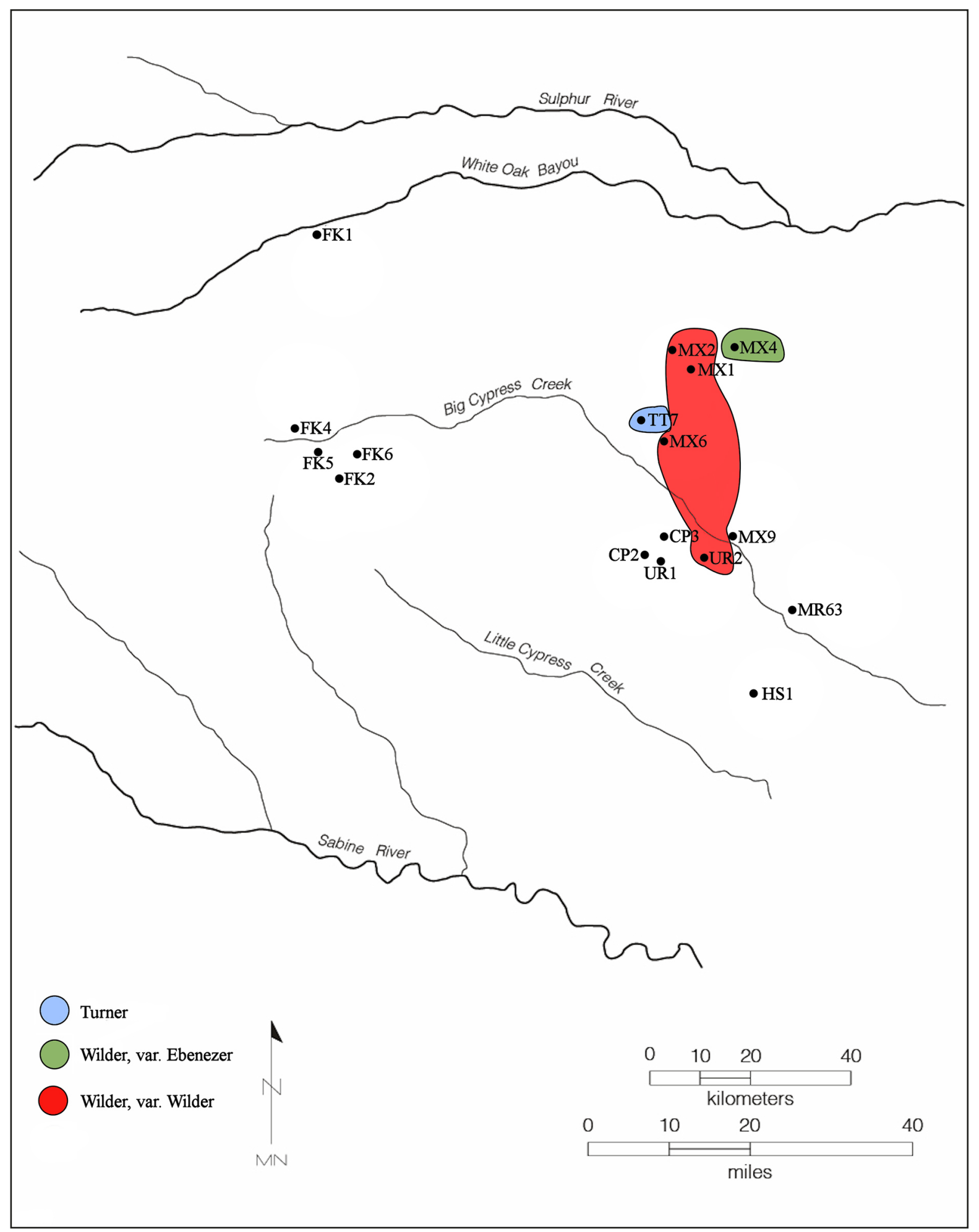

Figure 11. The distribution of sites with the highest proportion of Turner Engraved, var. Horton and var. Turner and Wilder Engraved, var. Ebenezer and var. Wilder vessels in selected Titus phase assemblages. 

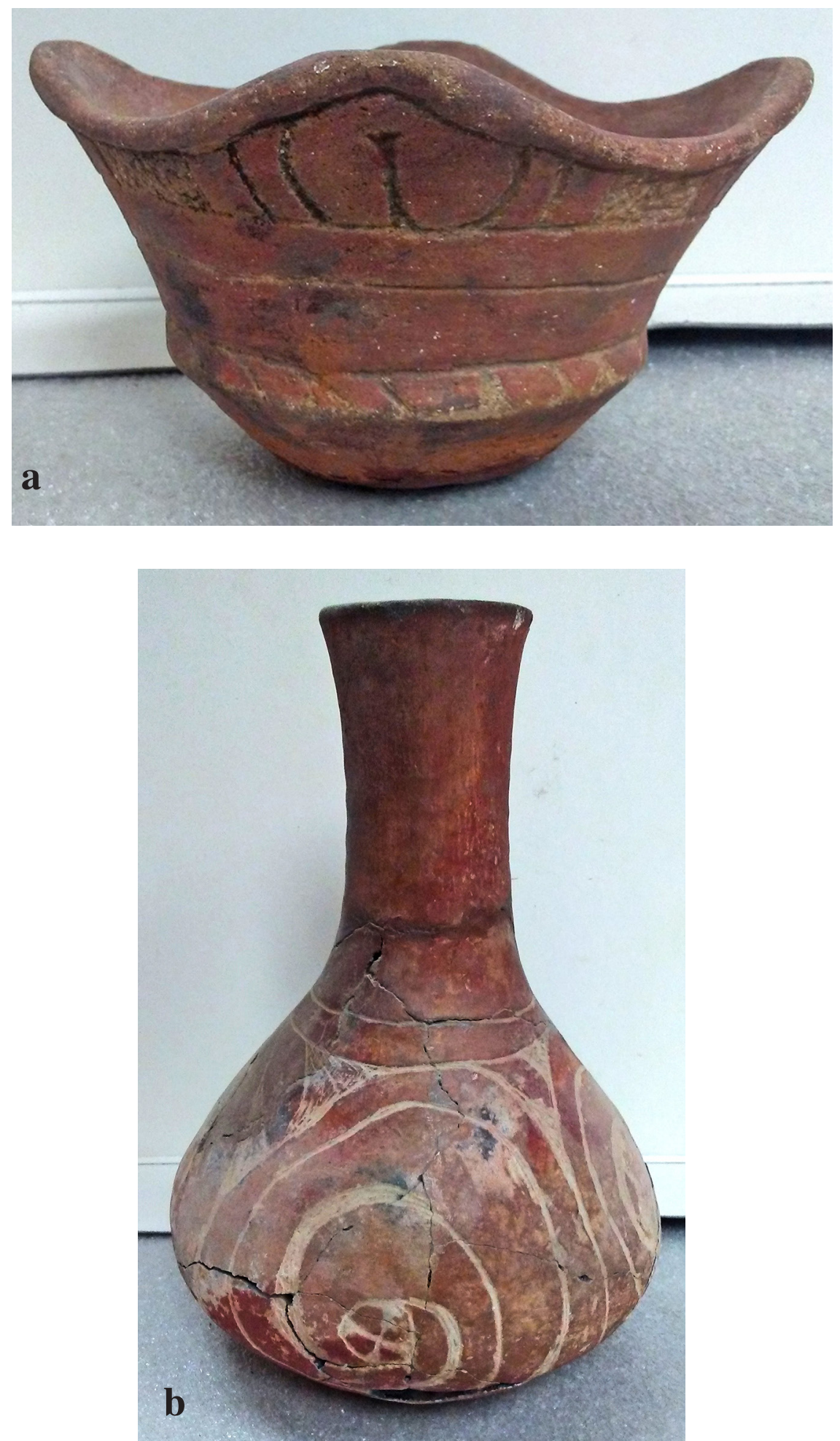

Figure 12. Turner Engraved and Wilder Engraved vessels in the study area: a, Turner Engraved, Vessel 20 at 41MX4; b, Wilder Engraved, Vessel 109 at $41 \mathrm{TT7}$. 
Finally, other fine wares, including several of non-local manufacture (Avery Engraved and Simms Engraved) (Figure 13a-b) in these Titus phase sites have distinctive spatial distributions. Avery Engraved vessels are most common at the J. E. Galt site (41FK2) in the upper Big Cypress Creek basin, while Bailey Engraved bottles are more abundant in northern and eastern Big Cypress Creek Titus phase sites (Figure 14). Simms Engraved vessels are best represented in White Oak Bayou and northern Big Cypress Creek sites, and Taylor Engraved vessels are concentrated in eastern Big Cypress Creek basin sites (Figure 14).
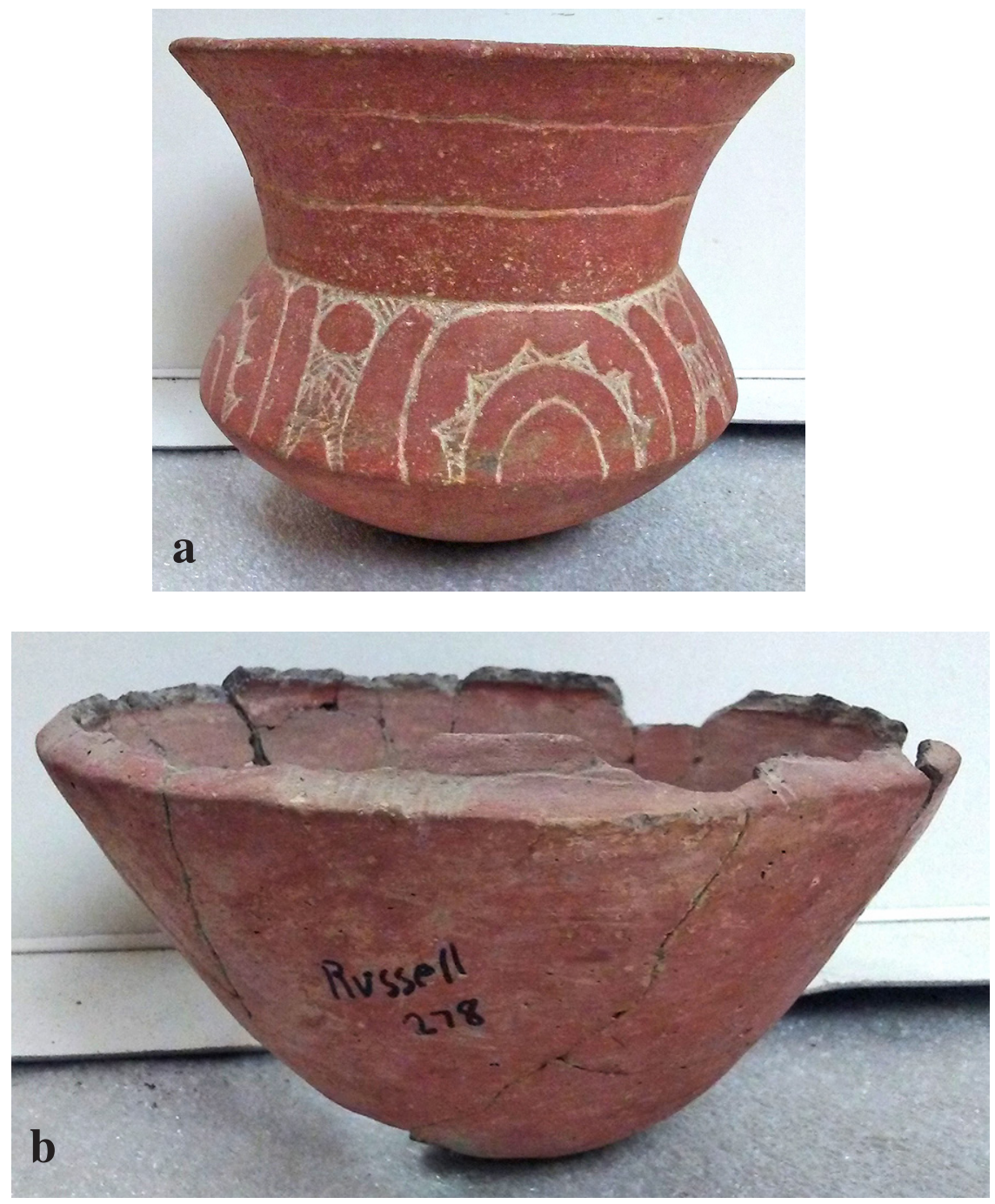

Figure 13. Avery Engraved and Simms Engraved vessels in the study area: a, Avery Engraved, Vessel 36 at 41TT7; b, Simms Engraved, Vessel 278 at 41TT7. 


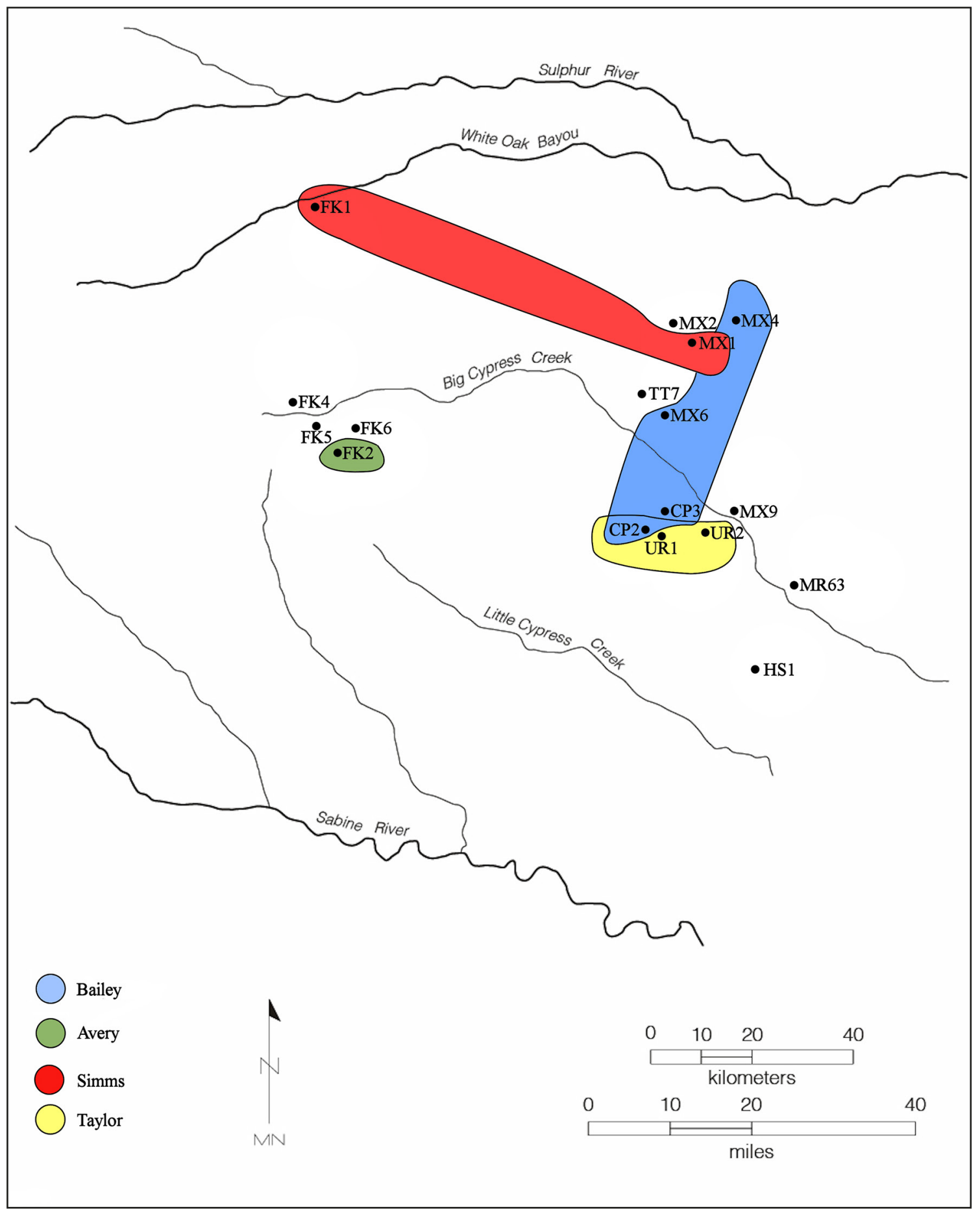

Figure 14. The distribution of sites with the highest proportion of Avery Engraved, Bailey Engraved, Simms Engraved, and Taylor Engraved vessels in selected Titus phase assemblages. 


\section{Utility Ware Types}

Utility ware vessels, almost always jars, are a common feature of the Titus phase vessel assemblages documented in this study. The most common identified and locally manufactured utility wares in these sites are La Rue Neck Banded (21.1 percent), Mockingbird Punctated (20.5 percent), Harleton Appliqued (19.8 percent), Maydelle Incised (12.4 percent), and Bullard Brushed (7.4 percent) (Table 11 and Figure 15a-c).

Table 11. Utility ware types in selected Titus phase ceramic assemblages.

\begin{tabular}{lllllllll}
\hline Type & CP2 & FK1 & FK2 & FK4 & MX1 & MX2 & MX4 & TT7 \\
\hline Belcher Ridged & - & - & - & 1 & - & - & - & - \\
Bullard Brushed & - & - & - & - & - & - & - & - \\
Cass Appliqued & 1 & - & 1 & - & - & - & 4 & 1 \\
Harleton Appliqued & 2 & - & 2 & 8 & 1 & - & 3 & 3 \\
Karnack Brushed-Incised & 2 & - & - & - & - & - & - & - \\
Killough Pinched & 1 & - & - & - & - & 2 & 2 & - \\
La Rue Neck Banded & - & 4 & 5 & 2 & 1 & 8 & 3 & 10 \\
Maydelle Incised & - & - & - & - & 2 & 3 & 4 & 8 \\
Mockingbird Punctated & 2 & - & 1 & 4 & 1 & 2 & 1 & 17 \\
Moore Noded & 2 & - & - & 1 & - & - & - & 3 \\
Nash Neck Banded* & - & - & - & - & - & 1 & - & - \\
Pease Brushed-Incised & - & - & - & - & - & - & - & 2 \\
\hline Totals & 10 & 4 & 9 & 16 & 5 & 16 & 17 & 44 \\
\hline
\end{tabular}

*non-locally manufactured utility ware type

Table 11. Utility ware types in selected Titus phase ceramic assemblages, cont.

\begin{tabular}{lllll}
\hline Type & UR1 & UR2 & N & Percent \\
\hline Belcher Ridged* & - & - & 1 & 0.6 \\
Bullard Brushed & 5 & 7 & 12 & 7.4 \\
Cass Appliqued & - & 1 & 8 & 5.0 \\
Harleton Appliqued & - & 13 & 32 & 19.8 \\
Karnack Brushed-Incised & - & 2 & 4 & 2.5 \\
Killough Pinched & - & - & 5 & 3.1 \\
La Rue Neck Banded & - & 1 & 34 & 21.1 \\
Maydelle Incised & 1 & 2 & 20 & 12.4 \\
Mockingbird Punctated & 3 & 2 & 33 & 20.5 \\
Moore Noded & - & 1 & 7 & 4.3 \\
Nash Neck Banded* & - & 1 & 2 & 1.2 \\
Pease Brushed-Incised & 1 & - & 3 & \\
\hline Totals & 10 & 30 & 161 & \\
\hline
\end{tabular}

*non-locally manufactured utility ware type

The five most common utility wares in the documented assemblages have different proportions across the study area (Figure 16). La Rue Neck Banded is best represented in Titus phase sites in the 

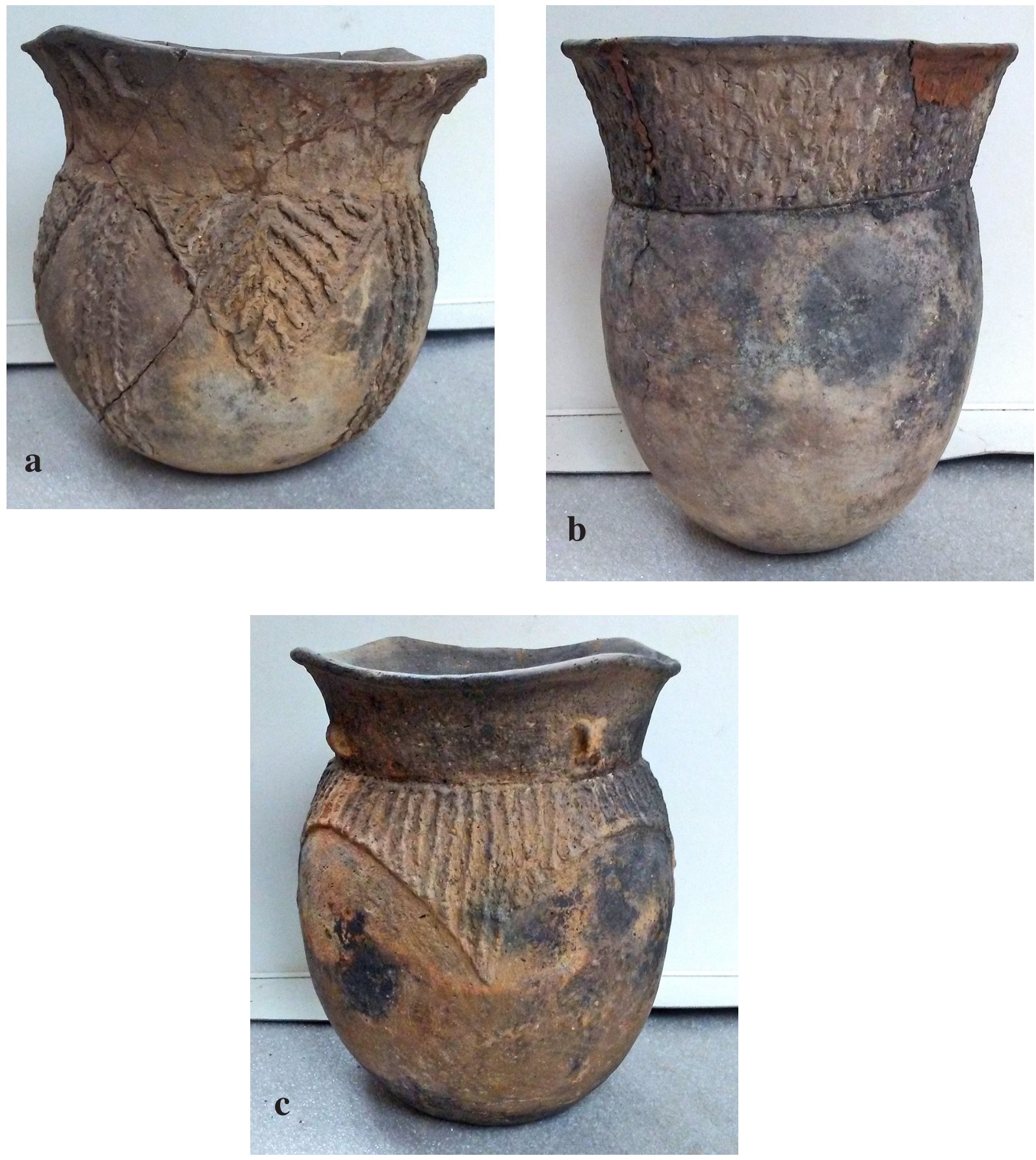

Figure 15. Selected utility ware types in the study area: a, La Rue Neck Banded, Vessel X3 at 41MX1; b, Mockingbird Punctated, Vessel 1 at 41TT7; c, Harleton Appliqued, Vessel.

western parts of the White Oak Bayou and Big Cypress Creek basins and in a northern Big Cypress Creek Titus phase site. Mockingbird Punctated jars are commonly distributed across much of the western and eastern Big Cypress Creek basin, as are Harleton Appliqued vessels (Figure 16). Maydelle Incised jars are most common in northern Titus phase sites, while Bullard Brushed jars are best represented in eastern Titus phase vessel assemblages (Figure 16). The less common utility ware types (with only 1.9-5.0 percent by type of the utility wares from all the sites, see Table 11) are mostly represented in northern, middle, and eastern Titus phase vessel assemblages (Figure 17). 


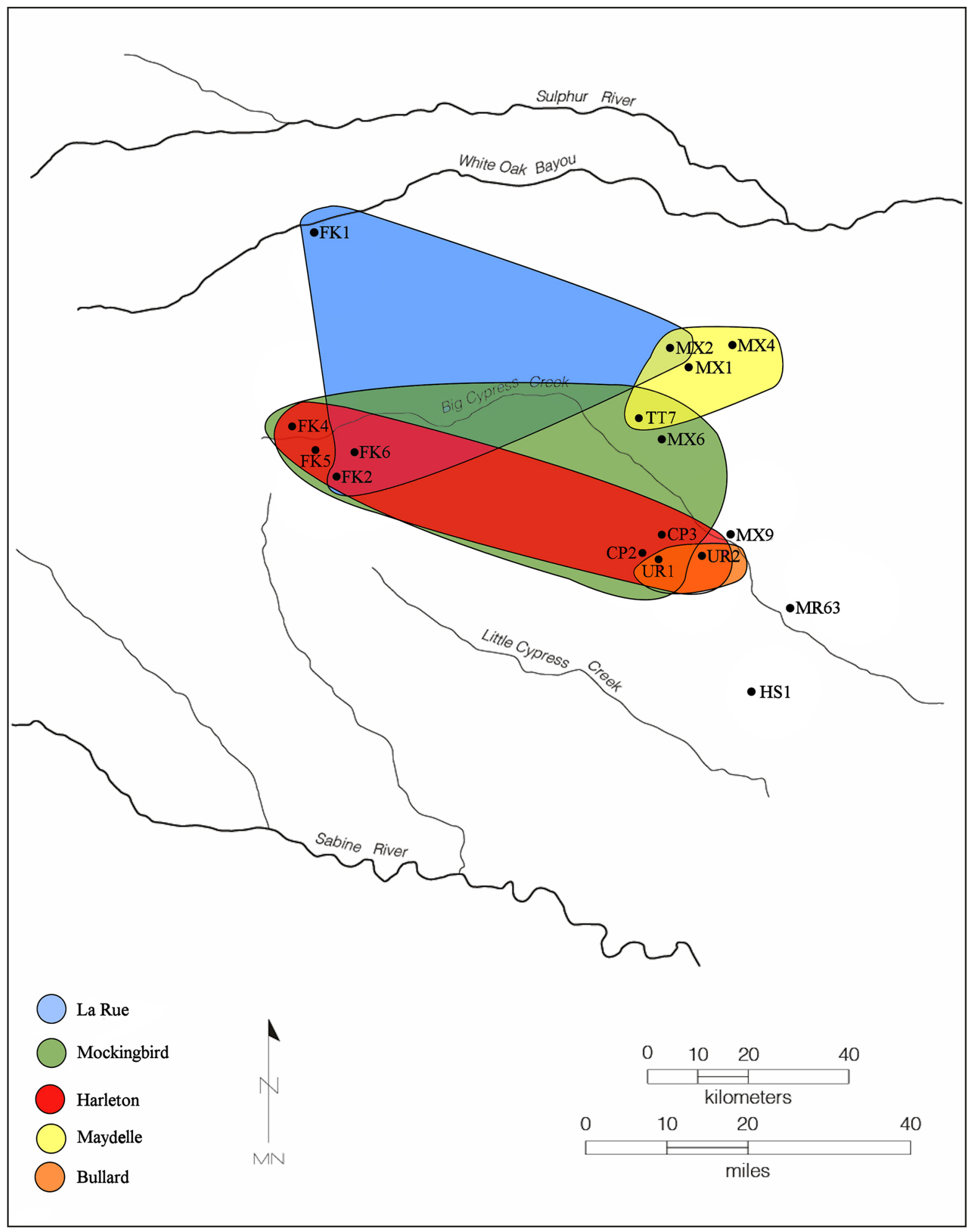

Figure 16. Distribution of the highest proportions of La Rue Neck Banded, Mockingbird Punctated, Harleton Appliqued, Maydelle Incised, and Bullard Brushed vessels in selected Titus phase assemblages. 


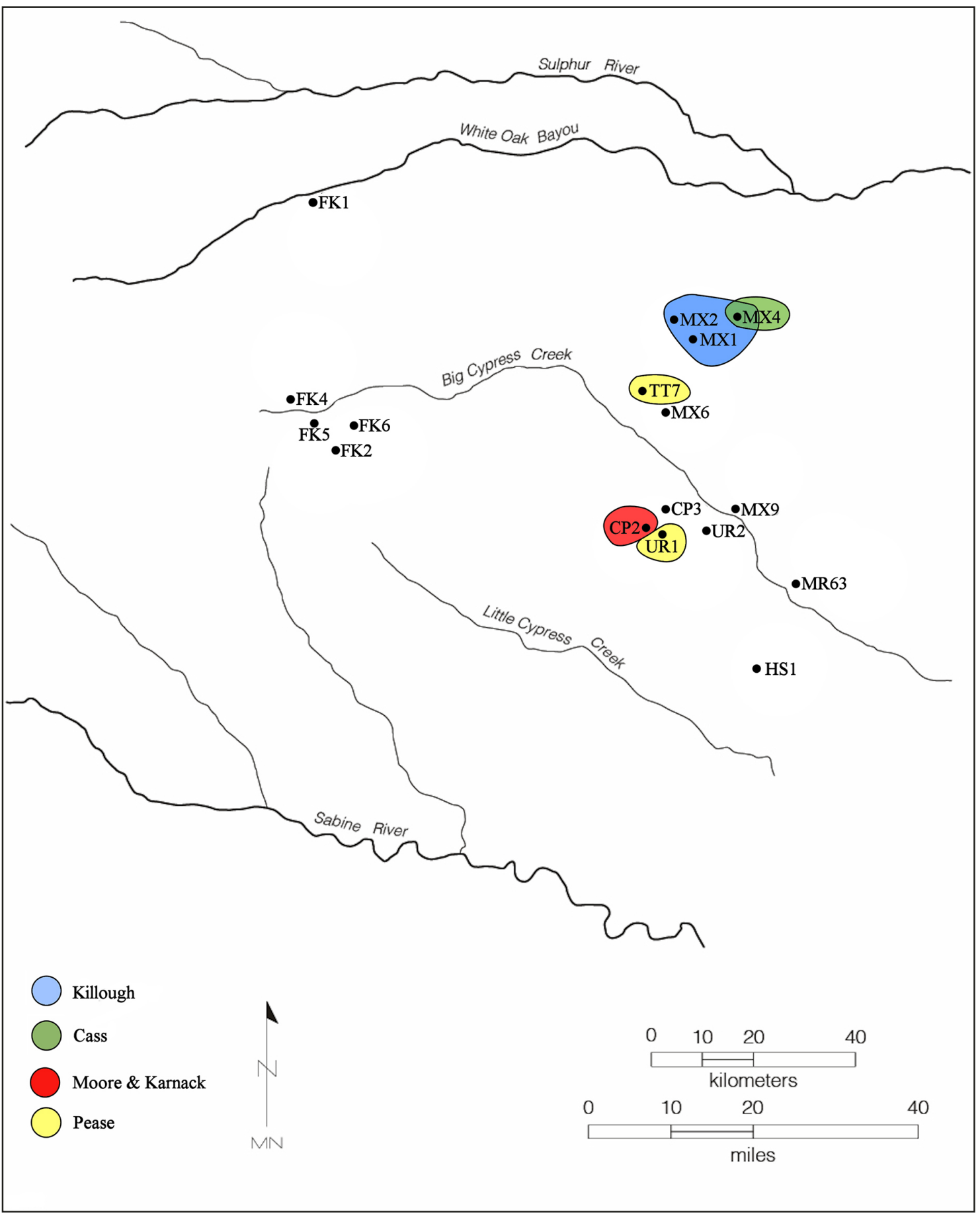

Figure 17. Distribution of the highest proportions of Killough Pinched, Cass Appliqued, Moore Noded, Karnack Brushed-Incised, and Pease Brushed-Incised vessels in selected Titus phase assemblages.

\section{Use of Red and Black Slips and Clay Pigments}

The use of slips on certain fine ware vessels is a notable feature of these Titus phase vessel assemblages, particularly red-slipped vessels in one site in the White Oak Bayou stream basin and in two sites in the upper Big Cypress Creek basin, all in Franklin County, Texas (Table 12 and Figure 18). In those sites between 12.3-26.3 percent of the fine ware vessels have a red slip; in the larger assemblage as a whole, only 9.5 percent of the fine ware vessels have a red slip. 
Table 12. Red and black slips on fine ware vessels in selected Titus phase assemblages.

\begin{tabular}{llllll}
\hline \multirow{2}{*}{ Sites } & \multicolumn{2}{l}{ Red Slip } & \multicolumn{2}{c}{ Black Slip } & \multirow{2}{*}{ No. of Fine Wares } \\
& No. & $\%$ & No. & $\%$ \\
\hline 41CP2 & - & - & - & - & 29 \\
41FK1 & 5 & 26.3 & - & - & 19 \\
41FK2 & 10 & 25.6 & - & - & 39 \\
41FK4 & 7 & 12.3 & - & - & 57 \\
41 MX1 & - & - & - & - & 24 \\
41 MX2 & 2 & 3.5 & - & - & 57 \\
41MX4 & 4 & 8.3 & - & - & 48 \\
41 TT7 & 16 & 9.7 & - & - & 165 \\
41UR1 & - & - & - & - & 13 \\
41UR2 & 9 & 8.3 & 2 & 1.9 & 108 \\
\hline Totals & 53 & 9.5 & 2 & 0.4 & 559 \\
\hline
\end{tabular}

Only one site in the larger Titus phase assemblages under study has black-slipped vessels, namely the J. M. Riley site (41UR2) (see Table 12 and Figure 18). These black-slipped vessels comprise 1.9 percent of the fine ware vessels from the site, but only 0.4 percent of all the fine ware vessels in the study area.

Titus phase potters commonly embellished the engraved designs on fine ware vessels by adding either a red hematite-rich clay pigment or a white kaolin clay pigment to the engraved designs (Table 13). In the assemblages documented in this study, 7.8 percent of the fine ware vessels have a red pigment in the engraved decorative elements, 23.0 percent have a white pigment, and 0.7 percent have both a white and red pigment applied to the engraved lines.

Table 13. Red, white, and white-red pigments on fine ware vessels in selected Titus phase assemblages.

\begin{tabular}{|c|c|c|c|c|c|c|c|}
\hline \multirow[t]{2}{*}{ Sites } & \multicolumn{2}{|c|}{ Red Pigment } & \multicolumn{2}{|c|}{ White Pigment } & \multicolumn{2}{|c|}{ White-Red Pigment } & \multirow[t]{2}{*}{ No. of Fine Wares } \\
\hline & No. & $\%$ & No. & $\%$ & No. & $\%$ & \\
\hline $41 \mathrm{CP} 2$ & 6 & 20.7 & 8 & 27.6 & - & - & 29 \\
\hline 41FK1 & 3 & 15.8 & 1 & 5.3 & - & - & 19 \\
\hline 41FK2 & 8 & 20.5 & 14 & 35.9 & 2 & 5.1 & 39 \\
\hline $41 \mathrm{FK} 4$ & 2 & 3.5 & 7 & 12.3 & - & - & 57 \\
\hline $41 \mathrm{MX} 1$ & 3 & 12.5 & 10 & 41.7 & - & - & 24 \\
\hline $41 \mathrm{MX} 2$ & 5 & 8.8 & 16 & 28.1 & - & - & 57 \\
\hline $41 \mathrm{MX} 4$ & 9 & 18.8 & 11 & 22.9 & 2 & 4.2 & 48 \\
\hline $41 \mathrm{TT7}$ & 4 & 2.4 & 38 & 23.0 & - & - & 165 \\
\hline 41UR1 & - & - & 2 & 15.4 & - & - & 13 \\
\hline 41UR2 & 4 & 3.7 & 22 & 20.4 & - & - & 108 \\
\hline Totals & 44 & & 129 & & 4 & & 559 \\
\hline Percent & & 7.8 & & 23.0 & & 0.7 & 31.5 \\
\hline
\end{tabular}




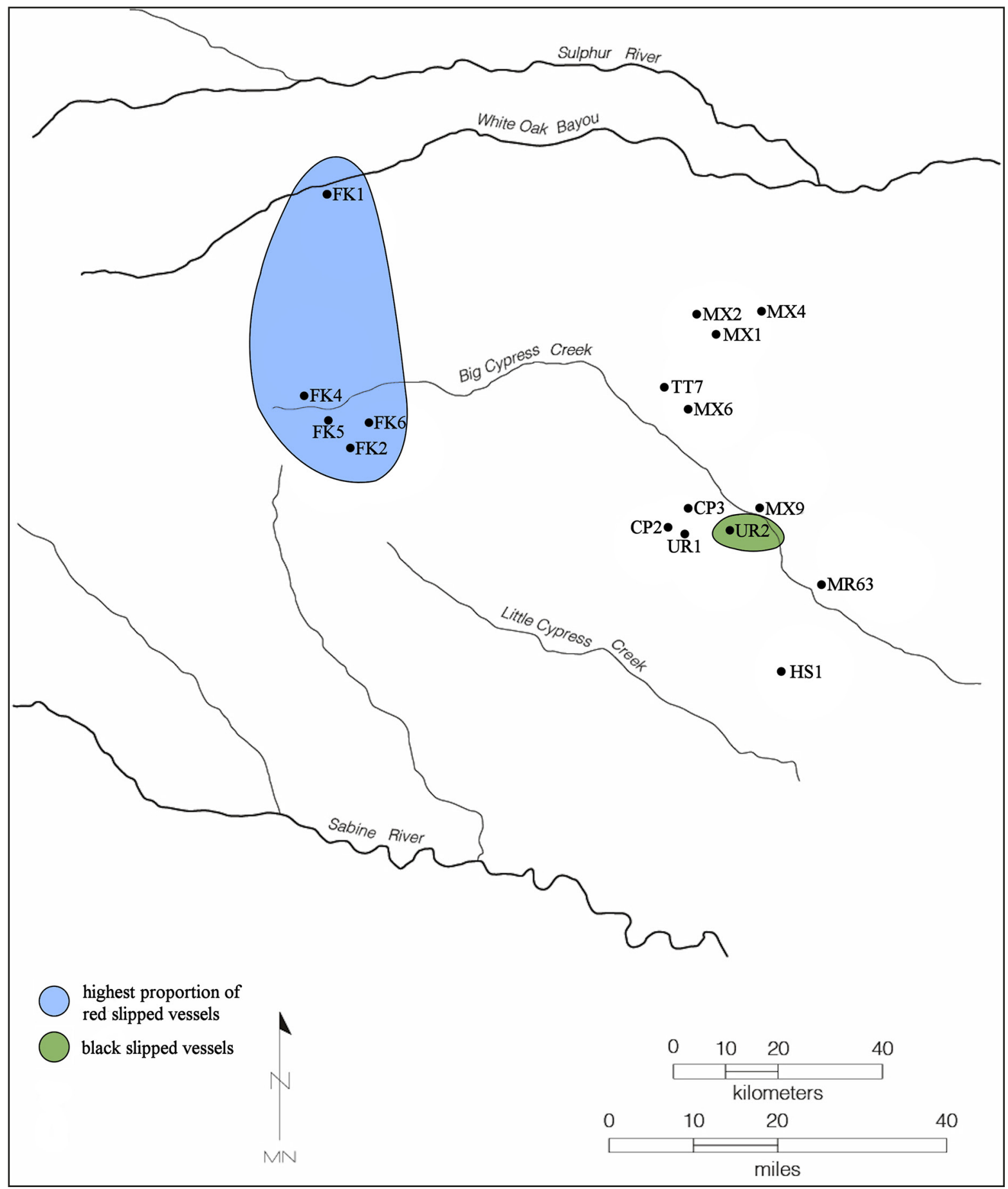

Figure 18. Distribution of the highest proportion of red-slipped fine ware vessels in sites in the study area, and the one site with black-slipped fine ware vessels.

The assemblages with the highest proportion of red pigment use on fine ware vessels (15.8-20.7 percent) are in the western part of the Big Cypress Creek and White Oak Bayou basins and in the middle to eastern part of the Big Cypress Creek basin (Figure 19). Fine ware assemblages with the highest proportions of white pigment use (27.6-41.7 percent) occur in sites in the same general area, except not in the one site in the White Oak Bayou basin (Figure 19). The two sites with fine ware vessels that have both red and white pigments on them are in the western and eastern parts of the Big Cypress Creek basin (Figure 19). 


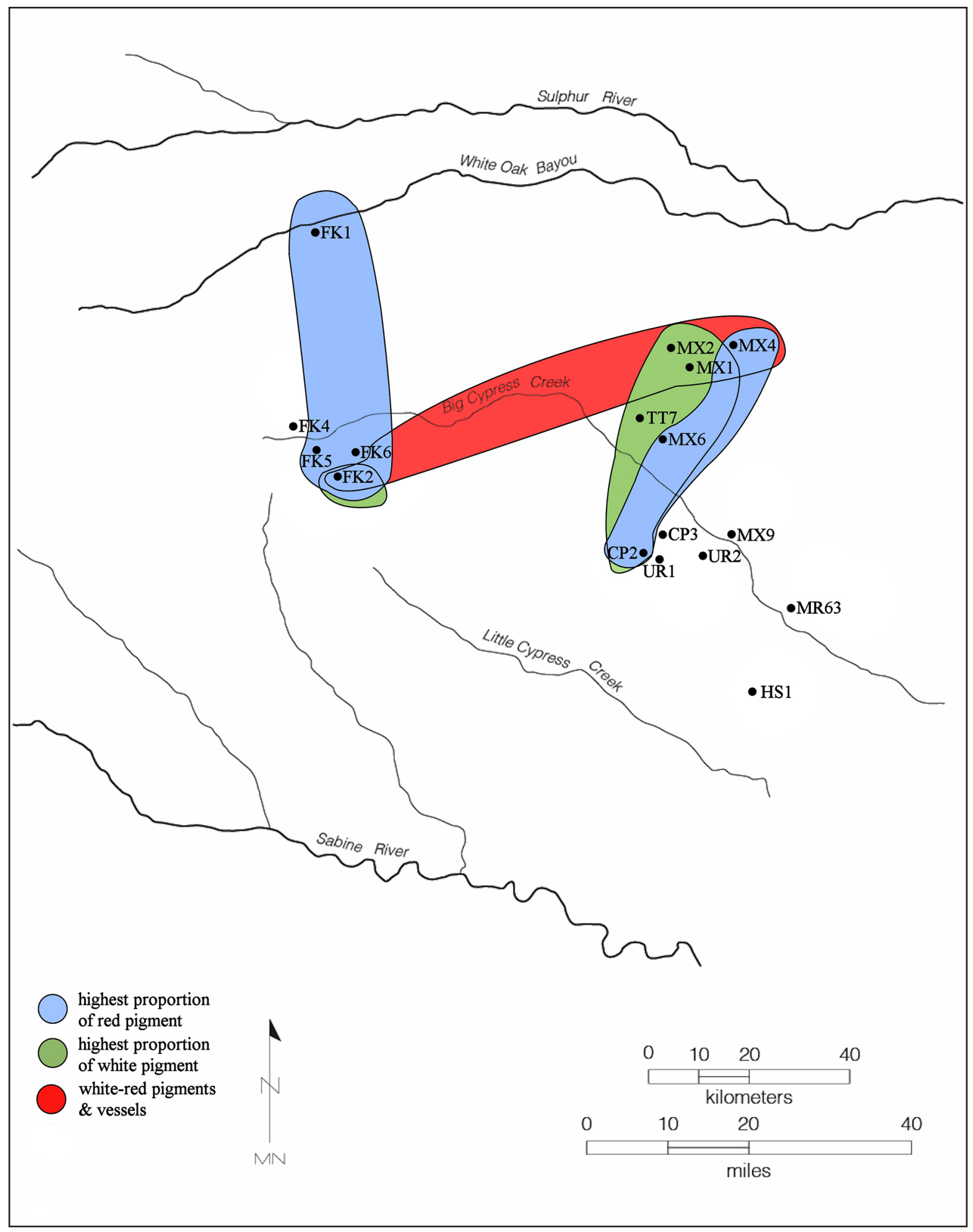

Figure 19. Titus phase vessel assemblages with the highest proportion of red and white pigments on fine ware vessels, and the distribution of sites with vessels with both red and white pigments. 


\section{Final Thoughts}

The ancestral Caddo ceramic tradition or sub-traditions represented in burial features from selected $15^{\text {th }}$ to $17^{\text {th }}$ century Titus phase sites of the Late Caddo period (ca. A.D. 1430-1680) in the Big Cypress Creek and Sulphur River basins in East Texas is one dominated by fine ware vessels (mainly carinated bowls, but with bottles and compound bowls also common) with engraved, engraved-red-slipped, and red-slipped decorative elements. The majority of the fine wares in the assemblages are represented by many defined varieties of Ripley Engraved, but other important and locally produced fine wares include Taylor Engraved, Turner Engraved, and Wilder Engraved vessels. Red-slipped vessels and fine ware vessels with an applied red or white pigment were common stylistic attributes chosen by ancestral Caddo potters in the vessel assemblages across the region.

Fine ware vessels of non-local manufacture, some shell-tempered, are a small subset of the fine wares; these include Avery Engraved, Belcher Engraved, Hodges Engraved, Hood Engraved, and Simms Engraved types. They were made in the Red River and Neches River basins by McCurtain, Belcher, and Frankston phase Caddo potters in what is now East Texas and Northwest Louisiana.

Common locally made utility wares in these Titus phase vessel assemblages include La Rue Neck Banded, Mockingbird Punctated, Harleton Appliqued, Maydelle Incised, and Bullard Brushed. One Belcher Ridged jar from the Mattie Gandy site (41FK4) was made by a Belcher phase Caddo potter, and the few Moore Noded bowls in the assemblages were likely also made by Belcher phase potters.

Both fine ware, utility ware, and plain wares in these Titus phase vessel assemblages were manufactured primarily using grog temper added to locally procured clays. Other important tempers added to the clay paste of vessels included crushed hematite and crushed burned bone. A small percentage of the vessels - all of non-local manufacture - were tempered with crushed and burned mussel shell. Vessels were made in a range of forms and sizes, ranging from small to very large in volume (in liters).

A significant proportion of the fine ware vessels in these Titus phase assemblages, almost all Ripley Engraved carinated bowls, have organic residue on their exterior vessel surfaces. These vessels appear to have been deliberately "smoked" or sooted in smoky fires as part of graveside rituals.

Although there is considerable homogeneity in the stylistic, formal, and technological character of these Titus phase vessel assemblages, the examination of the proportional and spatial differences from one assemblage to another in relative frequency of vessel wares, vessel forms, temper choices, fine ware and utility ware types, use of a red slip and red and white pigments on vessels, and the occurrence of exterior organic residues on fine ware vessels dispel the notion of complete homogeneity. Instead, within the Titus phase areas in the Big Cypress and Sulphur River basins, there are spatially distinct assemblages of site-vessel clusters (Figure 20) that can be viewed as distinct ceramic style zones and specific communities of practice across the landscape (see Worth 2017:150-151 and Figure 7.5).

These assemblages are part of distinctive social communities or networks of socially related individuals. The particular choices and tendencies exhibited in the manufacture and decoration of ceramics by Titus phase Caddo potters between ca. A.D. 1430-1680 indicate that temporally (and socially) related group of ancestral Caddo sites identified in the archaeological record, particularly the mortuary record when based on a study of complete vessels, are a means to recognize socially defined groups that closely interacted and transmitted knowledge between potters as a means of social learning. Social interactions between Titus phase communities must have been extensive across the landscape over more than two centuries. This knowledge of manufacture and decoration and stylistic choices was inherited by other descendant potters in these Titus phase groups. In this context, then, ceramic practices shared by women potters reflect the learning of their craft from other women in Titus phase Caddo 


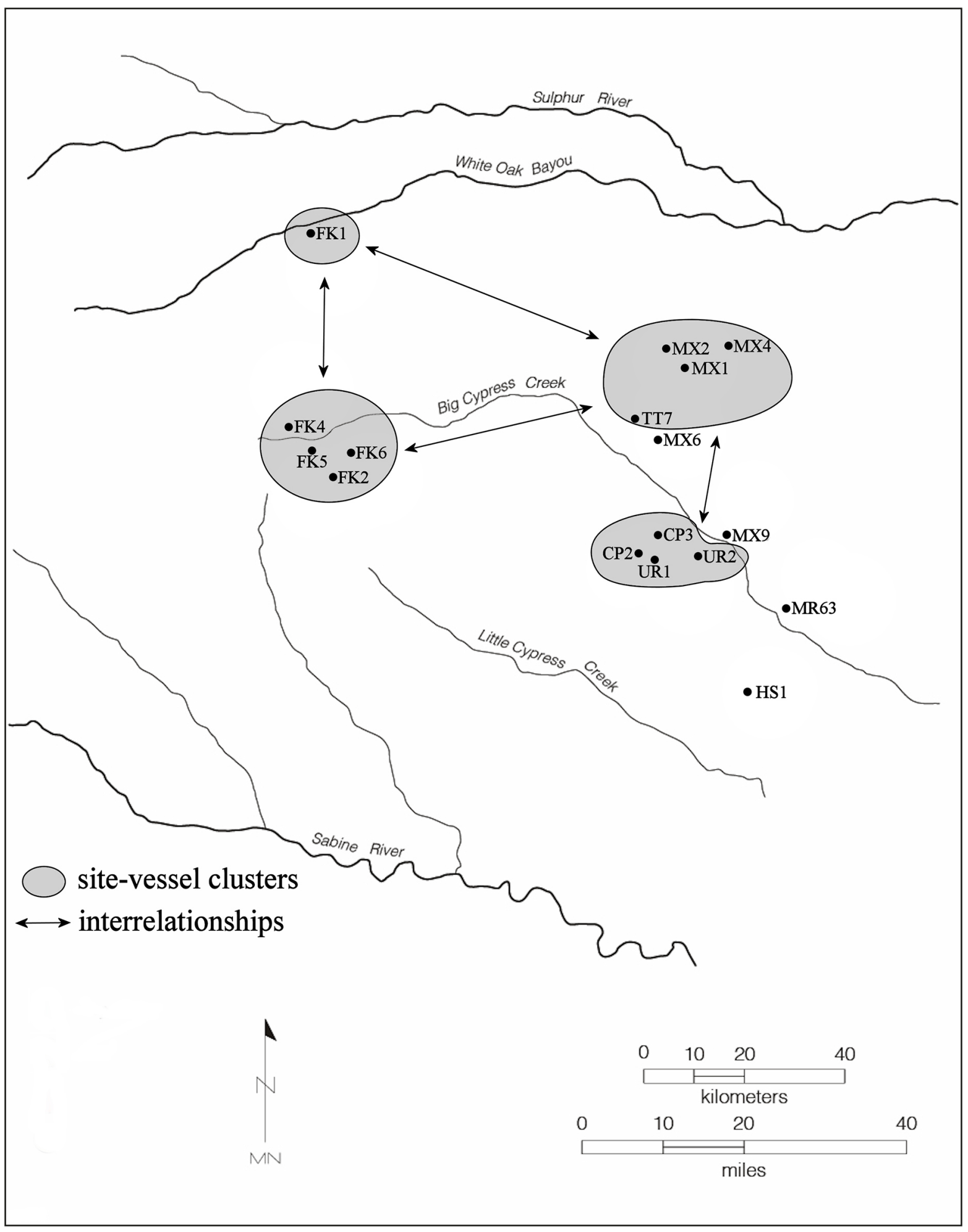

Figure 20. Recognized site-vessel clusters among the selected Titus phase vessel assemblages, and presumed interrelationships between the site-vessel clusters. 
communities, and that "patterns in local pottery styles, both technological and decorative, result from potters making different decisions throughout the production process but using a similar set of tools and techniques available to other potters within an area" (Eckert 2008:2).

\section{Acknowledgments}

Brian Wootan and Lance Trask prepared the figures for this article. I thank Marybeth Tomka for access to the ancestral Caddo vessel collections held by TARL.

Eckert, S. L.

\section{Referencs Cited}

2008 Pottery and Practice: The Expression of Identity at Pottery Mound and Hummingbird Pueblo. University of New Mexico Press, Albuquerque.

Fields, R. C., V. L. Hatfield, D. Burden, E. F. Gadus, M. C. Wilder, and K. W. Kibler

2014 Testing and Data Recovery Excavations at 11 Native American Archeological Sites along the U.S. Highway 271 Mount Pleasant Relief Route, Titus County, Texas. 2 Vols. Reports of Investigations No. 168. Prewitt \& Associates, Inc., Austin.

Perttula, T. K.

2018 A Study of Ancestral Caddo Ceramic Vessels from Titus Phase Sites in Camp, Franklin, Harrison, Marion, Morris, Titus, and Upshur Counties in East Texas. Special Publication No. 52. Friends of Northeast Texas Archaeology, Austin and Pittsburg.

Shott, M.

2018 Pottery Ethnoarchaeology in the Michoacan Sierra. The University of Utah Press, Salt Lake City.

Worth, J. E.

2017 What's in a Phase: Disentangling Communities of Practice from Communities of Identity in Southeastern North America. In Forging Southeastern Identities: Social Archaeology, Ethnohistory, and Folklore of the Mississippian to Early Historic South, edited by G. A. Waselkov and M. T. Smith, pp. 118-157. University of Alabama Press, Tuscaloosa. 